\section{Abstract}

\title{
Microstructure and mechanical properties of fibre reinforced asphalt mixtures
}

Conventional asphalt mixtures can perform satisfactorily in most flexible pavement and airfield applications. However, during recent years the trend has been towards traffic growth, severe climate conditions, and heavier loads. This allied to durability and cost effectiveness issues, has raised the demand to improve the mechanical properties of conventional asphalt materials by means of modification. Fibres may have the potential to achieve such modification and, thereby, enhance the mechanical properties of asphalt mixtures. This paper examines the relative performance of asphalt mixture modified with different fibre types and contents against the main distress types experienced by flexible pavements. Also, fibre distribution and orientation in the asphalt mixture are explored in this paper. The scanning electronic microscope images show the difference in the microstructure among fibre types. X-ray computed tomography investigation results indicate that steel fibres are present throughout the asphalt mixture specimen. The test results show that fibres have a notable impact on the stiffness modulus and fracture toughness of asphalt mixtures at $20^{\circ} \mathrm{C}$ test temperature. In addition, fibres provide slightly improved fatigue life of fibre reinforced asphalt mixtures, mainly at low strain values. Furthermore, results indicate that there is no detrimental impact of fibres on either the tensile strength or the moisture damage resistance of such mixtures.

Keywords: Fibre, Stiffness, Fibre distribution, Moisture damage, Microstructure, Fatigue, Fracture toughness. 


\section{Introduction}

There has been an increasing interest in modifying asphalt mixtures in order to improve their performance and the service life of pavements. Asphalt pavement performance is influenced mainly by three factors, axle loads, environmental temperature (since it is a viscoelastic material) and moisture [1, 2]. Many researchers have utilised different modifiers to improve asphalt mixture service quality [3, 4]. Among these modifiers different types of fibre such as steel, basalt, polypropylene and thermoplastics have been used [5-8]. The influence of fibres on asphalt mixtures is different to that of polymers including Styrene-Butadiene Rubber (SBR), Styrene-Butadiene-Styrene (SBS) and Polyethylene (PE). Fibres not only modify asphalt binder to prevent drain down in asphalt mixtures, but also enhance the mechanical properties such as viscoelasticity, rutting resistance, dynamic modulus, and reflective cracking [9-11].

A good quality pavement is fundamental to guarantee a long service life. Such a pavement must be capable of providing a smooth ride and high resistance to thermal cracking, withstand large traffic volumes and effectively transfer load to the underlying support. This paper examines the influence of different types and percentages of fibre on asphalt mixture stiffness, fatigue cracking resistance, moisture damage resistance and fracture toughness. Furthermore, X-ray computed tomography (CT) is used to observe the presence of steel fibres and their entanglement in the asphalt mixture, in order to provide a better understanding of the fibre reinforcing mechanism.

\section{Materials}

\subsection{Fibre types and properties}

Glass fibres of two lengths, cellulose fibres, and steel fibres recovered from tyres were selected for this study, and used as an additive to asphalt. Table 1 lists some basic properties of these fibres.

Micrographs showing glass and cellulose fibres are given in Figure 1 and Figure 2 respectively, using a scanning electronic microscope (SEM), and steel fibres viewed with an optical microscope (Nikon Digital Sight DS-Ri1) are shown in Figure 3. From these Figures, it can be seen that compared with the smooth glass and steel fibres, cellulose fibres are much rougher. The cellulose fibres are produced in uneven bundles, in which the fibre diameter can be as little as 1 micron and have a rough surface texture and irregular size. 


\subsection{Bitumen and asphalt mixtures}

64 A 40/60 pen binder was used in this study [12]. The properties of the bitumen and 65 limestone aggregate are shown in Table 2 and Table 3, respectively.

A $0 / 20 \mathrm{~mm}$ size binder course Dense Bitumen Macadam (DBM) was used [13]. The gradation for the $20 \mathrm{~mm}$ DBM is shown in Table 4, and Figure 4 shows the gradation design curve. This Figure shows the upper and lower limits and the mid way curve from the British Standard, as well as the actual aggregate gradation used. The binder content used in this mixture was $5 \%$ by total mixture weight.

\subsection{Mixing and compaction}

The required amounts of binder and aggregate for manufacturing asphalt mixtures were preheated at the required mixing temperature; three hours for the binder and eight hours for aggregate. The preheated aggregates were placed and mixed in a mechanical asphalt mixer for two minutes at the required mixing temperature. Then fibre was added into the mixer and mixed manually for a few seconds before the preheated binder was added to the batch, and the mixing continued for another three minutes according to BS EN 1269735 [14]. The asphalt was then poured into a preheated square mould and compacted by the roller compactor to the required thickness, to reach the target air voids ( $7 \%$ ) according to BS EN 12697-33 [15]. There was no clear influence of the fibre on the compaction effort.

\section{Experimental programme}

The experimental programme used in this study is shown in Table 5 . These tests are focused mainly on evaluating the most important mechanical properties of asphalt mixtures, in addition to their microstructure. The number of replicate tests and material variables are shown in Table 5.

\subsection{X-ray computed tomography imaging}

Fibre reinforced asphalt mixtures are complex, heterogeneous, multiple phase composites of fibres, mastics, aggregates and air voids. The performance of fibre reinforced asphalt mixture is highly dependent on the proportion of these components, in addition to their physical properties, quantity and distribution [16-18]. In asphalt mixtures, the fibre distribution and the way they interact with each other contributes significantly to their ability in spreading traffic loads. Therefore, their microstructure and distribution play a significant role in performance. 
A few studies have explored fibre distribution and entanglement within bituminous binder by using a SEM [19-21]. These studies found that fibre dimensions and surface textures have an influence on the formation of three dimensional networks. The network formed provides support to the composite structure by holding the components together and reducing stress concentration in addition to retaining bitumen at high temperatures [22].

However, so far, no research effort has been specifically dedicated to investigating the challenge of measuring the actual distributions of different types of fibre in the asphalt mixture. One part of this study was to explore the usefulness of using X-ray CT along with image analysis techniques to investigate the distribution and orientation of different fibre types in the asphalt mixtures. The advanced imaging facilities will help to achieve a better understanding of the asphalt mixture micro-structure and define the various parameters that may influence the internal structure and to link them to asphalt mixture mechanical properties.

X-ray CT was used to characterise 475 evenly spaced cross-sectional 'slices' through asphalt mixture core specimens of $48 \mathrm{~mm}$ thickness and $46 \mathrm{~mm}$ diameter, that were taken from slabs prepared using a roller compactor. The images show the differences in density at each point in each slice through the specimen. A number of studies have claimed that $\mathrm{X}$-ray CT is highly sensitive to small density differences between materials, as low as $1.0 \%$ $[23,24]$.

\subsection{Indirect tensile stiffness modulus (ITSM) test}

The indirect tensile stiffness modulus test (ITSM) as shown in Figure 5 was used to evaluate the stiffness modulus of control and fibre reinforced asphalt mixtures [25]. The Nottingham Asphalt Tester (NAT) was used for this test. In accordance with BS EN 1269726 , a compressive load pulse was applied with a rise time of $124 \pm 4 \mathrm{~ms}$ in order to produce a target horizontal deformation of $5 \pm 2 \mu \mathrm{m}$. The stiffness modulus was calculated as shown in the following equation:

$$
\operatorname{ITSM}=\frac{F}{(z h)} \times(v+0.27)
$$

where ITSM is the stiffness modulus (MPa), $F$ is the maximum load $(N), V$ is Poisson's ratio, $\mathrm{z}$ is the horizontal deformation $(\mathrm{mm})$ and $\mathrm{h}$ is the specimen thickness $(\mathrm{mm})$.

\subsection{Indirect tensile fatigue test (ITFT)}

The fatigue life of the asphalt mixtures was obtained through the indirect tensile fatigue test (ITFT). The test configuration is shown in Figure 6. In accordance with the Draft British 
127 standard [26], this test was made at a repeated constant load with $124 \pm 4$ ms loading

128 time and a pulse repetition time of $1.5 \pm 0.1 \mathrm{~s}$.

129 The tests were made in stress controlled loading mode (the applied load is held constant 130 during a test), at five different stress levels (150, 200, 300, 400 and $600 \mathrm{kPa})$, for each 131 asphalt mixture. In stress controlled loading mode the failure point of the test is when the 132 sample breaks, or the vertical deformation has reached $10 \mathrm{~mm}$, whichever occurs first 133 [26].

134 The ITFT test results of the bituminous mixtures are characterised as a function of the 135 applied strain according to equation (2).

$136 N_{f}=a \varepsilon_{0}^{-b}$

137 where $N_{f}$ is the number of load cycles to failure, $\varepsilon_{0}$ is the initial tensile strain at the middle 138 of the specimen (micro-strain), $a$ and $b$ are the coefficients obtained from the laboratory 139 test.

140 The resistance of asphalt mixtures to fatigue cracking was assessed in this study by the 141 following two parameters depending on the fatigue equations obtained for the mixtures $142[27,28]$.

- Strain value at one million cycles (micro-strain), and

- Fatigue life at one hundred micro-strain.

\section{$145 \quad 3.4$ Indirect tensile strength test (ITS)}

146 An Instron 1332 hydraulic loading frame was used for evaluating the indirect tensile 147 strength of control and fibre reinforced asphalt mixtures at $20^{\circ} \mathrm{C}$ test temperature [29]. 148 The Instron loading frame fitted with a load cell was used to apply compressive loading 149 through the vertical axis of the specimen with a $50 \mathrm{~mm} / \mathrm{min}$ displacement rate. The 150 experimental setup of the ITS test is shown in Figure 7. The ITS was calculated for each 151 specimen as shown in the equation below:

$152 \quad$ ITS $=\frac{2 F}{(\pi \times d \times t)}$

153 where $F$ is the vertical load $(N), d$ is the specimen diameter $(\mathrm{mm})$ and $t$ is the thickness 154 of the specimen ( $\mathrm{mm}$ ). 
155

156

157

158

159

160

161

162

163

164

165

166

167

168

169

170

171

172

173

174

175

176

177

178

179

180

181

182

183

184

185

186

187

\subsection{Moisture damage test}

The moisture sensitivity test was made according to BS EN 12697-12 [30]. Five core specimens for each mixture were obtained from roller compacted slabs. These were divided into two groups. Two dry specimens were placed in a water bath at $40^{\circ} \mathrm{C}$ for a period of 68 to 72 hours, wrapped in plastic wrap, in a sealed bag, followed by conditioning in a $20^{\circ} \mathrm{C}$ thermostatically controlled air cabinet for more than three hours.

The moisture conditioned specimens (three samples) were submerged in water and subjected to vacuum for a period of thirty minutes under $6.7 \mathrm{kPa}$ pressure, and then conditioned at $40^{\circ} \mathrm{C}$ in a water bath for 68 hours, followed by conditioning in a $20^{\circ} \mathrm{C}$ water bath for more than three hours prior to testing. Then, the dry and wet specimens were tested for indirect tensile strength, according to BS EN 12697-23 [29], with a $50 \mathrm{~mm} / \mathrm{min}$ constant displacement rate. The moisture damage test results are reported as an Indirect Tensile Strength Ratio (ITSR), which is the ratio of the wet strength to the dry strength, expressed as a percentage.

\subsection{Repeated load axial test (RLAT)}

This test was used to evaluate the permanent deformation resistance of asphalt mixture according to BS EN 12697-25 [31] using the Nottingham Asphalt Tester (NAT). During this test, asphalt mixture specimens are exposed to a repetitive harversian load and the vertical deformation after each repeated load was measured by means of two linear variable differential transformers (LVDTs) attached on the surface of the loading frame. In this paper the test conditions were $30^{\circ} \mathrm{C}$ test temperature, with 5000 cycles test duration, 30 pluses per minute and an axial stress of $100 \mathrm{kPa}$.

\subsection{Semi-circular bending test (SCB)}

The semi-circular bending test ( $\mathrm{SCB}$ ), as shown in Figure 8, was used to examine the fracture toughness $\left(\mathrm{K}_{\mathrm{i}}\right)$ (crack growth toughness) and maximum stress $(\sigma)$ at failure of asphalt mixtures according to BS EN 12697-44 [32]. Experiments were conducted on specimens supported by two rollers with a span length equal to 0.8 times the diameter under three point bending load configuration. A previous study recommended using rollers as supports so that the friction between the specimen and the support is reduced [33].

The Nottingham Asphalt Tester (NAT) was used for this test. This machine applied a monotonic load with a constant rate of displacement $(1 \mathrm{~mm} / \mathrm{min})$ until failure, while recording the test results (load vs displacement).

The maximum stress at failure $\left(\sigma_{\max }\right)$ was calculated according to the following equation: 
where $D$ is the diameter, $t$ is the sample thickness both in millimetres, and $F$ is the maximum force on the sample in Newtons.

191 The fracture toughness $\left(\mathrm{K}_{\mathrm{i}}\right)$ was calculated according to the following equation:

192

$K_{i}=\sigma_{\max } \times f\left(\frac{a_{i}}{W_{i}}\right)$

$\left(\mathrm{N} / \mathrm{mm}^{3 / 2}\right)$

193 where $W_{i}$ is the height of the specimen, $a_{i}$ is the notch depth, both in $\mathrm{mm}$, and $f\left(\frac{a_{i}}{W_{i}}\right)$ is a 194 geometric factor. The geometric value $f\left(\frac{a_{i}}{W_{i}}\right)$ is 5.956 , for $9<a_{i}<11 \mathrm{~mm}$ and $70<W_{i}<$ $19575 \mathrm{~mm}$. For other $\mathrm{a}_{i}$ and $\mathrm{W}_{\mathrm{i}}$ values, the geometric value can be calculated according to the 196 following equation:

$f\left(\frac{a_{i}}{W_{i}}\right)=-4.9965+155.58\left(\frac{a_{i}}{W_{i}}\right)-799.94\left(\frac{a_{i}}{w_{i}}\right)^{2}+2141.9\left(\frac{a_{i}}{W_{i}}\right)^{3}-2709.1\left(\frac{a_{i}}{w_{i}}\right)^{4}+1398.6\left(\frac{a_{i}}{w_{i}}\right)^{5}$

\section{Results and Discussion}

200

201

202

203

204

205

206

207

208

209

210

211

212

213

214

\subsection{X-ray CT image results}

The imaging process can be summarised in three steps: image acquisition, followed by image processing, and then image analysis. An advantage of using X-ray CT imaging is that by creating cross-sectional images, they can be used by specific programs, such as image $\mathrm{J}$, in the rebuilding of a volumetric (three dimensional) image of any specimen. A greyscale 8 bit image consisting of 256 levels was used in this study. The intensity value ranged from 0 (black) to 256 (white) for each element in the image. Image quality plays a significant role in the accuracy of any information extracted. Therefore, great care was taken to enhance the image and filter out noise. This was done by using a Gaussian filter and by excluding very small areas of similar intensity. The image J program was used to analyse the results and to rebuild a volumetric three-dimensional distribution of fibres as shown in Figure 9.

Although there is slight noise in rebuilding the volumetric distribution, it can be seen from Figure 9 that, in the case of steel fibres, the individual fibres were oriented in different directions (horizontal, vertical and inclined at different angles) inside the asphalt mixture specimen, forming a three dimensional network. It is clear from Figure 10 that steel fibres 
216 are distributed throughout the specimen. It can be noted that the total area of steel fibres

217 is slightly higher in the depth range 25 to $40 \mathrm{~mm}$ compared to other parts of the specimen.

218 An attempt was made to investigate the distribution of other fibre types (glass and 219 cellulose) in the same way. The test results were not clear enough to analyse due to the 220 similarity in the density of these fibres and other asphalt mixture components.

\section{$221 \quad 4.2$ Indirect tensile stiffness test results}

222 Figure 11 shows the indirect tensile stiffness test results of the control and fibre reinforced 223 asphalt mixtures at $20^{\circ} \mathrm{C}$. Error bars represent plus and minus one standard error. Adding 224 more fibres led to increases in the stiffness of the asphalt mixtures, especially for short 225 glass fibre and cellulose fibre. T-test results showed that the stiffness value of fibre 226 reinforced asphalt mixture significantly increased, compared to control specimens, as show 227 in Table 6. Stiffness modulus values of asphalt mixtures containing $2.0 \%$ glass-l, steel, 228 cellulose and glass-s fibre are about $21 \%, 26 \%, 28 \%$ and $32 \%$ higher than the stiffness 229 modulus value of the control mixture, respectively. This increase in stiffness modulus of 230 fibre reinforced asphalt mixture may be due to two reasons.

231 Firstly, any absorption/adsorption of the light bitumen fraction(s) by fibres will lead to 232 increased bitumen stiffness $[16,34]$. Previous studies, using the same fibres, showed that 233 they increase the stiffness of bitumen [21] and that the asphaltene content of drained 234 binder after mixing with fibres increased compared to the base binder, particularly for 235 cellulose fibres [35]. Moreover, the complex modulus value of the drained binder after 236 mixing with fibres showed a marked increase compared to the base binder. This 237 demonstrates that the influence of the fibres on the properties of the bitumen and resulting 238 mastic, is manifest in the properties of the mixtures made using these fibre reinforced 239 binders.

240 The second reason is the reinforcement mechanism of the fibre distributing the stress over

241 a large area due to the three-dimensional network; this network can be seen in the X-ray 242 CT image in Figure 9 and is also apparent in the fracture surfaces of the SCB test 243 specimens, see section 4.7 and Figure 16.

\section{$244 \quad 4.3$ Indirect tensile fatigue test results}

245 The fatigue results for control and fibre-reinforced asphalt mixtures are presented in 246 Figures 12-14, while the fatigue equations (Eq. (2)) for all control and fibre reinforced 247 asphalt mixtures together and their $R^{2}$ values are shown in Table 7 . These fatigue equations show high $\mathrm{R}^{2}$ values for both control and fibre reinforced asphalt mixtures. 
With regard to the fatigue performance of control and fibre reinforced asphalt mixtures, the fatigue life in Figure 12 and Figure 13 and the fatigue parameters for the fibre modified asphalt mixtures in Table 7, confirm the difference in the fatigue performance of fibre modified asphalt mixtures at $0.5 \%$ and $1.0 \%$ fibre content, particularly for steel fibres. At the 100 micro-strain level, the $0.5 \%$ and $1.0 \%$ fibre reinforced asphalt mixtures showed approximately 1.5 and 2.5 and 1.8 and 2.8, times higher fatigue life for steel and long glass fibres, respectively. These values are 2.3 and 1.1 times higher for $1.0 \%$ cellulose and short glass fibres respectively, compared to the control mixture at $20^{\circ} \mathrm{C}$ test temperature. At $2.0 \%$, the cellulose fibre was the only fibre that showed higher fatigue life compared to the control mixture at the 100 microstrain level and $20^{\circ} \mathrm{C}$ test temperature. However, at high strain level, the control mixture in general exhibited higher fatigue life than the fibre reinforced mixtures. This finding indicates that the fibre reinforced asphalt mixtures perform better only at low strain values and this is in agreement with a previous study [36]. The improvement in fatigue life is due to the fibre reinforcement effect as shown in the three dimensional X-ray CT image analysis (see Figure 9 for steel fibres). Fibre networks may perform as bridges, relocating and spreading stresses which may delay crack propagation and maintain greater strain before material failure, resulting in longer fatigue life. The improvement in fatigue cracking resistance could also be attributed to the fibre's adhesion in the mastic.

\subsection{Indirect tensile strength test results}

Indirect tensile strength results of control and fibre reinforced asphalt mixtures at $20^{\circ} \mathrm{C}$ are shown in Figure 15. The error bars represent plus and minus one standard error. It can be seen that glass-s and cellulose fibre reinforced asphalt mixtures showed a slight increase in the indirect tensile strength but only steel fibre reinforced asphalt mixture showed a marked increase, reaching 32\% higher than the control mixture. T-test results showed that there is not a significant increase in the indirect tensile strength of fibre reinforced asphalt mixtures compared to control specimens, see Table 8. It is interesting to note that most glass and steel fibre reinforced samples after testing at $20^{\circ} \mathrm{C}$ did not split in two, while all control and most cellulose mixture samples spilt at the end of the test. This is due to the residual strength provided by the fibres bridging the crack, as shown in Figure 16.

\subsection{Moisture damage test results}

The results of indirect tensile strength (ITS) and indirect tensile strength ratio (ITSR) follow no clear trend as shown in Figure 17, Figure 18 and Figure 19. The ITS values improve when the samples are exposed to the moisture damage procedure. These results 
are in line with those of previous studies [10, 37-39]. A possible explanation for this might be that the limestone aggregate chemistry (hydrophobic) and the action of conditioning in warm water at $40^{\circ} \mathrm{C}$ for more than 68 hours, may have led to slight ageing of the dense asphalt specimens, which can play a role in increasing the indirect tensile strength of the conditioned specimens [40]. This finding may indicate that the water conditioning is not harsh enough for dense asphalt mixture made with limestone aggregate and $7 \%$ target air voids.

Another issue is that the failure mode in the ITS test is not pure tension but it is a combination of tensile, compressive and shear failures. It is clear that compression and shear occur at locations near to the loading cell at the top of the specimen during the ITS test [41] (see Figure 20). The plastic deformation at the top of the specimen under the loading cell may redistribute the stress and may change the effective strain rate in the centre of the specimen where tension occurs. Therefore, the influence of moisture damage on tensile strength measured from the maximum load may be quite complex and unpredictable [41].

In light of these results it was decided to investigate the influence of the moisture damage procedure on weaker specimens. Therefore, the moisture damage resistance of RLAT specimens was explored and this is detailed in the following section.

\subsection{Results of moisture damage in RLAT specimens}

All RLAT specimens used in this test were exposed to a repetitive harversian load at $30^{\circ} \mathrm{C}$ test temperature with 5000 cycles test duration, 30 pluses per minute and an axial stress of $100 \mathrm{kPa}$, prior to soaking. As shown in Figure 21, Figure 22 and Figure 23 all RLAT specimens showed an ITSR higher than $80 \%$, with no systematic difference between control and fibre reinforced samples. The reduction in the ITS of asphalt mixtures after RLAT testing compared to new specimens is expected because these samples have cracks after being exposed to 5000 load pulses in the RLAT test. This might help water to penetrate further inside these specimens and cause damage. However, due to the limited number of specimens used in this investigation, it would be worth investigating this further. It is important to note that both control and fibre reinforced asphalt mixtures performed equally well with regards to moisture damage resistance.

\subsection{Semi-circular bending test results}

The SCB test result, fracture toughness $\left(\mathrm{K}_{\mathrm{i}}\right)$, has been used as a fracture assessment parameter by several researchers under different test conditions [42-44]. Fracture toughness $\left(\mathrm{K}_{\mathrm{i}}\right)$ of thirteen asphalt mixtures with different fibre types and contents is shown 
318 in Figure 24 and Figure 25. Three replicates were used for each asphalt mixture. Error 319 bars represent plus and minus one standard error. The SCB test was performed at two 320 test temperatures $\left(20^{\circ} \mathrm{C}\right.$ and $\left.0^{\circ} \mathrm{C}\right) \cdot 20^{\circ} \mathrm{C}$ was chosen to be the same as for the ITS and ITFT 321 tests, while $0^{\circ} \mathrm{C}$ was selected to examine the influence of fibre reinforcement on low 322 temperature cracking of asphalt mixture.

323 The fracture toughness at $20^{\circ} \mathrm{C}$ increased gradually with the increase in fibre content and 324 led to significant improvement mainly at $2.0 \%$, as T-test results compared to control 325 specimens show, in Table 9. There are several possible explanations for this result. Firstly, 326 the ability of fibre networks in delaying crack propagation by spreading the stress across 327 a larger area may lead to a reduction in the stress concentration caused by the cracks 328 [45]. This is one of the reasons for significant improvement in fracture toughness at $20^{\circ} \mathrm{C}$ 329 of $2.0 \%$ long glass fibre reinforced asphalt mixture due to the presence of a large number 330 of fibres in the notch area compared to glass-s and steel fibres. This was investigated by 331 visual observation after the test, as shown in Figure 26. Also, for fibres with higher 332 length/diameter ratio the formation of the network will produce more interweaving [46]. 333 It should be noted that glass and steel fibre reinforced samples after testing at $20^{\circ} \mathrm{C}$ did 334 not split in two, while most cellulose and all control mixture samples spilt after the test 335 was completed.

336 Another reason for these results is the ability of fibre to absorb/adsorb bitumen fractions 337 resulting in stiffer bitumen as shown in drain down test results in previous work [35]. 338 According to a previous study it was found that binder with higher stiffness showed higher 339 fracture toughness [47]. It is interesting to note that while the increase in fracture 340 toughness due to the fibres is more apparent at $0^{\circ} \mathrm{C}$ than at $20^{\circ} \mathrm{C}$, the trend with increasing 341 fibre content is more scattered. This is due to the fracture at $0^{\circ} \mathrm{C}$ being through a 342 combination of both aggregate and mastic as shown in Figure 27. Adding fibre to asphalt 343 mixtures generally resulted in slight improvement in the average fracture toughness at $3440^{\circ} \mathrm{C}$, although there is a large degree of scatter in the results. Such an improvement can 345 enhance the resistance of asphalt mixture to low temperature cracking.

346 The maximum stress and peak load were evaluated, as shown in Figure 28, Figure 29, 347 Figure 30 and Figure 31 . The maximum stress and peak load increased when fibres were 348 added. This confirms the increased stiffness of fibre-reinforced mixtures. 


\section{Conclusions}

351

352

353

354

355

356

357

358

359

360

361

362

363

364

365

366

367

368

369

370

371

372

373

374

375

376

377

378

379

This paper has examined the influence of different fibre types and amounts on the mechanical properties of asphalt mixture, by means of fatigue cracking resistance, moisture damage resistance and fracture toughness based on ITFT, ITSR and SCB, respectively. The study has also explored the fibre presence and distribution in the asphalt mixture by using X-ray CT and image analysis. Based on the discussion and analysis presented in this paper, the following conclusions are offered:

- Steel fibre distribution and orientation has been investigated successfully, using Xray $\mathrm{CT}$. This technique was not successful for glass or cellulose fibres, which have a density similar to other components of the mixture.

- It was found that steel fibres are present throughout the mixture, although there is some variability in their distribution through the sample. Images showed that the steel fibres are arranged at a variety of angles, forming a three dimensional network throughout the sample.

- The fibres increased the stiffness of the asphalt mixtures, by modification of the bitumen mastic (as demonstrated by previous studies) and by spreading load through the fibre networks in the mixture.

- The fatigue life of modified asphalt mixtures was higher than that of the control mixture at low strain values for fibre contents $0.5 \%$ and $1.0 \%$. The fatigue life of the control samples was higher at high strain values.

- Adding $2.0 \%$ glass and steel fibre to the asphalt mixture results in lower fatigue life compared to other fibre contents and the control mixture.

- Indirect tensile strength of asphalt mixture is improved when fibres are added. Steel fibres showed the highest improvement among all fibre types.

- Control and fibre reinforced asphalt mixtures exhibited high resistance to moisture damage and their ITS improved after being exposed to the moisture damage procedure.

- Specimens after RLAT testing were more susceptible to moisture damage. No systematic difference was found between control and fibre reinforced specimens. 
- Fibre reinforced asphalt mixtures showed higher fracture toughness than the control mixture. Fracture toughness at $20^{\circ} \mathrm{C}$ test temperature shows a statistically significant increase, with the increase in fibre content.

- Adding fibres showed an improvement in the low temperature cracking resistance of asphalt mixtures. They exhibited higher fracture toughness and maximum stress compared to the control mixture at $0^{\circ} \mathrm{C}$ test temperature.

- The extensive range of mechanical tests used in this study lead to one general conclusion: Adding these fibres enhances the properties of asphalt mixture in tests designed to assess their performance with respect to the predominant modes of deterioration in flexible pavements, that is, moisture damage, stiffness, low temperature cracks and fatigue life.

397

398

Table 1 Basic properties of fibres

\begin{tabular}{|c|c|c|c|c|}
\hline $\begin{array}{l}\text { Fibre } \\
\text { types }\end{array}$ & $\begin{array}{c}\text { Specific } \\
\text { density } \\
\left(\mathrm{g} / \mathrm{cm}^{3}\right)\end{array}$ & Length $(\mu \mathrm{m})$ & $\begin{array}{l}\text { Width of } \\
\text { individual } \\
\text { fibres } \\
(\mu \mathrm{m})\end{array}$ & $\begin{array}{l}\text { Modulus of } \\
\text { elasticity at } \\
23^{\circ} \mathrm{C} \text { (GPa) }\end{array}$ \\
\hline Glass-L & 2.58 & 13,000 & 12 to 20 & 80.3 \\
\hline Glass-S & 2.58 & 6,000 & 12 to 20 & 80.3 \\
\hline Cellulose & 1.50 & 20 to 2,500 & $\sim 25$ & - \\
\hline Steel & 7.85 & 4,000 to $\sim 12,000$ & 180 to 300 & $210 *$ \\
\hline
\end{tabular}

(398

\begin{tabular}{|l|c|c|}
\hline \multicolumn{1}{|c|}{ Property } & Value & Standard \\
\hline Specific gravity $\left(\mathrm{g} / \mathrm{cm}^{3}\right)$ & 1.03 & BS 2000-549:2007 \\
\hline Penetration value at $25^{\circ} \mathrm{C}$ & 54 & BS EN 1426:2007 \\
\hline
\end{tabular}




\begin{tabular}{|l|c|l|}
\hline Softening Point $\left({ }^{\circ} \mathrm{C}\right)$ & 51 & BS EN 1426:2015 \\
\hline Viscosity at $135^{\circ} \mathrm{C}(\mathrm{mPa} . \mathrm{s})$ & 446.9 & BS EN 13302:2010
\end{tabular}

400

401

402

Table 3 Properties of limestone aggregate

\begin{tabular}{|c|c|c|c|}
\hline \multicolumn{2}{|c|}{ Property } & Value & Standard \\
\hline $\begin{array}{c}\text { Particle } \\
\text { density }\end{array}$ & $\begin{array}{c}\text { Oven dried } \\
\text { Saturated surface dried } \\
\text { Apparent }\end{array}$ & $\begin{array}{c}2.68 \mathrm{Mg} / \mathrm{m}^{3} \\
2.69 \mathrm{Mg} / \mathrm{m}^{3}\end{array}$ & BS 812-2 \\
& $\begin{array}{c}2.71 \mathrm{Mg} / \mathrm{m}^{3} \\
\text { Water Absorption }\end{array}$ & \\
\hline Aggregate crushing value (ACV) & $0.6 \%$ & BS 812-2 \\
\hline \multicolumn{2}{|c|}{ Los Angles coefficient (LA) } & 23 & BS 812-110 \\
\hline
\end{tabular}

403

404

405

Table 4 0/20mm size DBM specification

\begin{tabular}{|c|c|}
\hline $\begin{array}{c}\text { Test sieve aperture size } \\
(\mathbf{m m})\end{array}$ & $\begin{array}{c}(\%) \\
\text { Passing of Combined } \\
\text { Aggregate }\end{array}$ \\
\hline 31.5 & 100 \\
\hline 20.0 & $95-100$ \\
\hline 14.0 & $65-85$ \\
\hline 10.0 & $52-72$ \\
\hline 6.3 & $38-56$ \\
\hline 2.0 & $20-40$ \\
\hline 0.25 & $6-20$ \\
\hline 0.063 & $2-9$ \\
\hline
\end{tabular}

Table 5 Experimental programme

\begin{tabular}{|c|c|c|c|c|}
\hline Materials & Variables & Test methods & $\begin{array}{c}\text { Test } \\
\text { replicate }\end{array}$ & $\begin{array}{c}\text { Test } \\
\text { temperature }\end{array}$ \\
\hline Fibre & $\begin{array}{c}\text { Fibre } \\
\text { content by } \\
\text { reinforced }\end{array}$ & $\begin{array}{c}\text { Indirect tensile stiffness } \\
\text { modulus (ITSM) }\end{array}$ & 10 & $20^{\circ} \mathrm{C}$ \\
bitumen & $\begin{array}{c}\text { Indirect tensile fatigue test } \\
\text { (ITFT) }\end{array}$ & 1 & $20^{\circ} \mathrm{C}$ \\
mixture & $\begin{array}{c}\text { volume } \\
0.5 \%\end{array}$ & & & \\
& $1.0 \%$ & & & \\
\hline
\end{tabular}




\begin{tabular}{|c|c|c|c|}
\hline $\begin{array}{c}2.0 \% \\
\text { Fibre type } \\
\text { Glass-L }\end{array}$ & $\begin{array}{c}\text { Dry indirect tensile strength } \\
\text { (ITS) }\end{array}$ & 2 & $20^{\circ} \mathrm{C}$ \\
\hline $\begin{array}{c}\text { Glass-S } \\
\text { Cellulose } \\
\text { Steel }\end{array}$ & $\begin{array}{c}\text { Wet indirect tensile strength } \\
\text { (ITS) }\end{array}$ & 3 & $20^{\circ} \mathrm{C}$ \\
\cline { 2 - 4 } & $\begin{array}{c}\text { Moisture damage } \\
\text { Moisture damage for RLAT } \\
\text { samples }\end{array}$ & 5 & $20^{\circ} \mathrm{C}$ \\
\hline $\begin{array}{c}\text { Semi-circular bending test } \\
\text { (SCB) }\end{array}$ & 3 & $20^{\circ} \mathrm{C}$ \\
\hline
\end{tabular}

406

407

408

409

410

411

412

Table 6 T-test for stiffness of control and fibre reinforced asphalt mixtures

\begin{tabular}{|l|l|l|l|l|}
\hline \multicolumn{1}{|c|}{$\begin{array}{c}\text { Asphalt } \\
\text { mixtures }\end{array}$} & $\begin{array}{c}\text { Mean } \\
(\mathbf{M P a})\end{array}$ & T-stat & P-value & Significant* \\
\hline Control & 2629.8 & - & - & - \\
\hline $0.5 \%$ Glass-S & 2910.2 & 2.652 & 0.0226 & Yes \\
\hline $0.5 \%$ Glass-L & 2860.2 & 2.699 & 0.0122 & Yes \\
\hline $0.5 \%$ Cellulose & 2757.1 & 1.458 & 0.0842 & No \\
\hline $0.5 \%$ Steel & 3119.6 & 6.476 & 0.00003 & Yes \\
\hline $1 \%$ Glass-S & 3113.7 & 2.923 & 0.0111 & Yes \\
\hline $1 \%$ Glass-L & 3086.6 & 3.882 & 0.0012 & Yes \\
\hline $1 \%$ Cellulose & 3300.3 & 5.950 & 0.0009 & Yes \\
\hline $1 \%$ Steel & 3238.0 & 4.307 & 0.0062 & Yes \\
\hline $2 \%$ Glass-S & 3481.4 & 3.447 & 0.0068 & Yes \\
\hline $2 \%$ Glass-L & 3184.3 & 6.684 & 0.00002 & Yes \\
\hline $2 \%$ Cellulose & 3371.6 & 2.928 & 0.0163 & Yes \\
\hline $2 \%$ Steel & 3317.8 & 6.103 & 0.0001 & Yes \\
\hline
\end{tabular}

413

* Indicates significant at the 95 percent confidence interval.

414

415 
Table 7 Summary data for all the asphalt mixtures tested during this study using the

\begin{tabular}{|c|c|c|c|c|c|c|c|}
\hline $\begin{array}{c}\text { Mixture } \\
\text { type }\end{array}$ & $\begin{array}{l}\text { Fatigue } \\
\text { Equation }\end{array}$ & $\begin{array}{c}\varepsilon @ 10^{6} \\
\text { cycles } \\
(\mu \varepsilon)\end{array}$ & Rank & $\begin{array}{l}\text { Fatigue } \\
\text { Equation }\end{array}$ & $\begin{array}{c}N_{f} \\
@ 100^{\mu \varepsilon}\end{array}$ & Rank & $R^{2}$ \\
\hline Control & $\varepsilon=5219 N_{f}-0.345$ & 44.4 & 8 & $N_{f}=3 \times 10^{10} \varepsilon^{-2.794}$ & 77,468 & 8 & 0.97 \\
\hline $0.5 \%$ Steel & $\varepsilon=2853.9 N_{f}-0.274$ & 64.8 & 3 & $N_{f}=2 \times 10^{12} \varepsilon^{-3.481}$ & 218,288 & 1 & 0.95 \\
\hline $0.5 \% \mathrm{Gl}-\mathrm{L}$ & $\varepsilon=2588.1 N_{f}-0.274$ & 58.7 & 4 & $N_{f}=1 \times 10^{12} \varepsilon^{-3.462}$ & 119,124 & 5 & 0.95 \\
\hline $0.5 \% \mathrm{Gl}-\mathrm{S}$ & $\varepsilon=3663.7 N_{f}-0.318$ & 45.3 & 7 & $N_{f}=1 \times 10^{11} \varepsilon^{-3.128}$ & 55, & 12 & 0.99 \\
\hline $0.5 \%$ Cell & $\varepsilon=5075.4 N_{f}-0.350$ & 40.3 & 10 & $N_{f}=2 \times 10^{10} \varepsilon^{-2.726}$ & 70,637 & 9 & 0.96 \\
\hline $1 \%$ Steel & $\varepsilon=3788.5 N_{f}-0.292$ & 67.1 & 2 & $N_{f}=1 \times 10^{12} \varepsilon^{-3.355}$ & 194,984 & 2 & 0.98 \\
\hline $1 \% \mathrm{Gl}-\mathrm{L}$ & $\varepsilon=3827.1 N_{f}^{-0.309}$ & 46.0 & 6 & $N_{f}=4 \times 10^{11} \varepsilon^{-3.230}$ & 138,695 & 4 & 0.99 \\
\hline $1 \% \mathrm{Gl}-\mathrm{S}$ & $\varepsilon=4495 N_{f}-0.336$ & 43.3 & 9 & $N_{f}=5 \times 10^{10} \varepsilon^{-2.890}$ & 82,979 & 7 & 0.97 \\
\hline $1 \%$ Cell & $\varepsilon=1920.5 N_{f}^{-0.241}$ & 68.8 & 1 & $N_{f}=2 \times 10^{13} \varepsilon^{-4.024}$ & 179,073 & 3 & 0.97 \\
\hline $2 \%$ Steel & $\varepsilon=4001.3 N_{f}-0.333$ & 40.2 & 11 & $N_{f}=6 \times 10^{10} \varepsilon^{-2.978}$ & 66,397 & 10 & 0.99 \\
\hline $2 \% \mathrm{Gl}-\mathrm{L}$ & $\varepsilon=4519.4 N_{f}-0.353$ & 34.4 & 13 & $N_{f}=7 \times 10^{9} \varepsilon^{-2.619}$ & 40,467 & 13 & 0.92 \\
\hline $2 \% \mathrm{Gl}-\mathrm{S}$ & $\varepsilon=4215.3 N_{f}-0.339$ & 39.0 & 12 & $N_{f}=3 \times 10^{10} \varepsilon^{-2.860}$ & 57,164 & 11 & 0.97 \\
\hline $2 \%$ Cell & $\varepsilon=3271.5 N_{f}^{-0.296}$ & 55.0 & 5 & $N_{f}=2 \times 10^{11} \varepsilon^{-3.175}$ & 89,337 & 6 & 0.94 \\
\hline
\end{tabular}

Table 8 T-test for indirect tensile strength of control and fibre reinforced asphalt mixtures

\begin{tabular}{|l|l|l|l|l|}
\hline \multicolumn{1}{|c|}{$\begin{array}{c}\text { Asphalt } \\
\text { mixtures }\end{array}$} & $\begin{array}{c}\text { Mean } \\
(\mathbf{M P a})\end{array}$ & T-stat & P-value & Significant* \\
\hline Control & 1.053 & - & - & - \\
\hline $0.5 \%$ Glass-S & 1.164 & 2.626 & 0.059 & No \\
\hline $0.5 \%$ Glass-L & 1.064 & 0.231 & 0.419 & No \\
\hline $0.5 \%$ Cellulose & 1.156 & 2.969 & 0.103 & No \\
\hline $0.5 \%$ Steel & 1.285 & 1.605 & 0.177 & No \\
\hline $1 \%$ Glass-S & 1.162 & 1.833 & 0.104 & No \\
\hline $1 \%$ Glass-L & 1.066 & 0.179 & 0.437 & No \\
\hline $1 \%$ Cellulose & 1.058 & 0.116 & 0.463 & No \\
\hline $1 \%$ Steel & 1.135 & 0.648 & 0.316 & No \\
\hline $2 \%$ Glass-S & 1.179 & 2.634 & 0.059 & No \\
\hline $2 \%$ Glass-L & 1.106 & 1.420 & 0.195 & No \\
\hline $2 \%$ Cellulose & 1.167 & 3.333 & 0.092 & No \\
\hline $2 \%$ Steel & 1.302 & 2.514 & 0.120 & No \\
\hline
\end{tabular}

$421 *$ Indicates significant at the 95 percent confidence interval. 
Table 9 T-test for fracture toughness of control and fibre reinforced asphalt mixtures

\begin{tabular}{|c|c|c|c|c|}
\hline $\begin{array}{c}\text { Asphalt } \\
\text { mixtures }\end{array}$ & $\begin{array}{c}\text { Mean } \\
\left(\mathrm{N} / \mathbf{m m}^{3,2}\right)\end{array}$ & T-stat & P-value & Significant* \\
\hline Control & 5.132 & - & - & - \\
\hline $0.5 \%$ Glass-S & 5.260 & 0.957 & 0.219 & No \\
\hline $0.5 \%$ Glass-L & 5.129 & 0.007 & 0.497 & No \\
\hline $0.5 \%$ Cellulose & 5.291 & 0.273 & 0.414 & No \\
\hline $0.5 \%$ Steel & 5.521 & 1.951 & 0.061 & No \\
\hline $1 \%$ Glass-S & 5.311 & 0.313 & 0.392 & No \\
\hline $1 \%$ Glass-L & 5.619 & 1.340 & 0.136 & No \\
\hline $1 \%$ Cellulose & 5.864 & 3.338 & 0.014 & Yes \\
\hline $1 \%$ Steel & 5.623 & 2.132 & 0.037 & Yes \\
\hline $2 \%$ Glass-S & 5.646 & 1.017 & 0.247 & No \\
\hline $2 \%$ Glass-L & 7.192 & 14.819 & 0.002 & Yes \\
\hline $2 \%$ Cellulose & 6.064 & 3.674 & 0.033 & Yes \\
\hline $2 \%$ Steel & 5.593 & 2.951 & 0.023 & Yes \\
\hline
\end{tabular}

423

* Indicates significant at the 95 percent confidence interval.

424

425

426
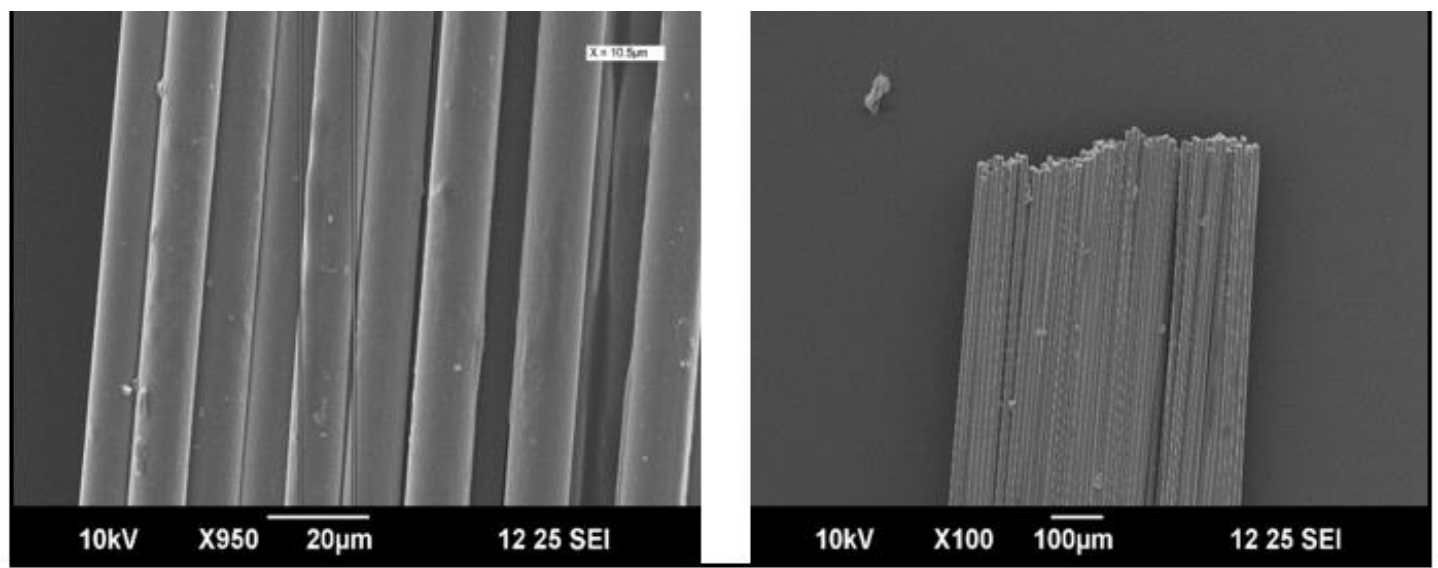

Figure 1 Scanning Electron Microscope (SEM) images of glass fibre 


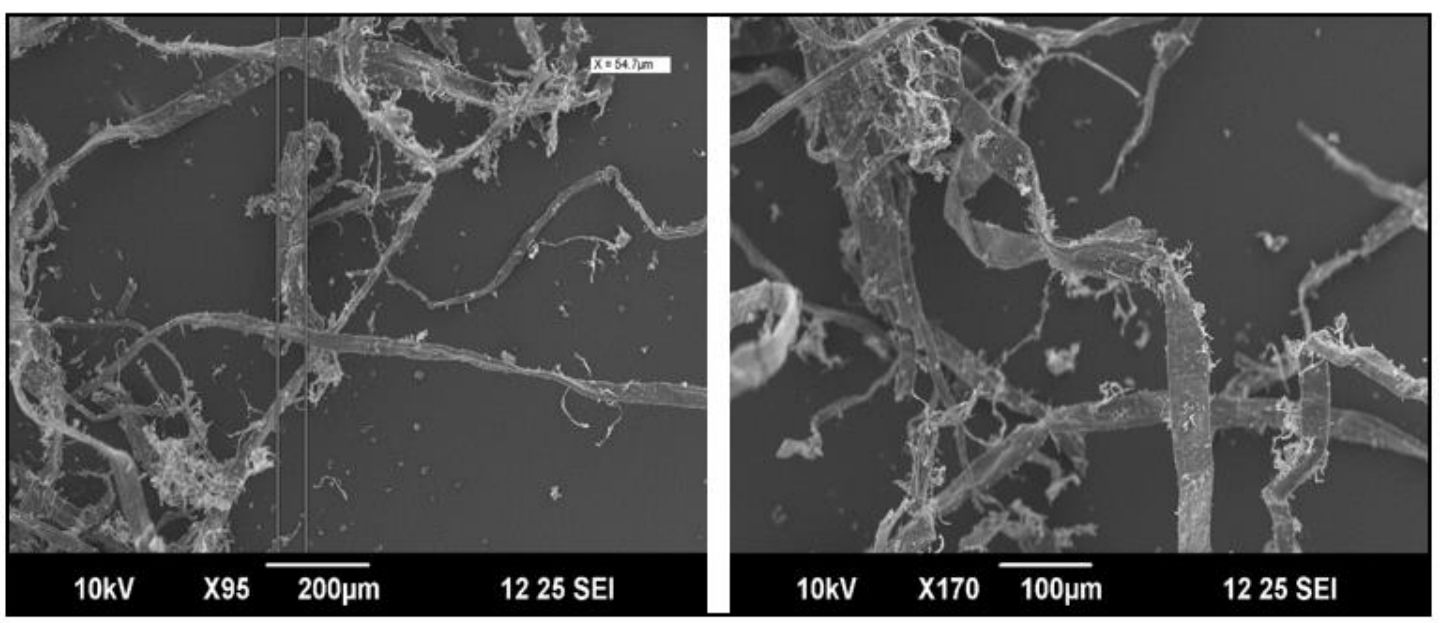

Figure 2 Scanning Electron Microscope (SEM) images of cellulose fibre

431

432

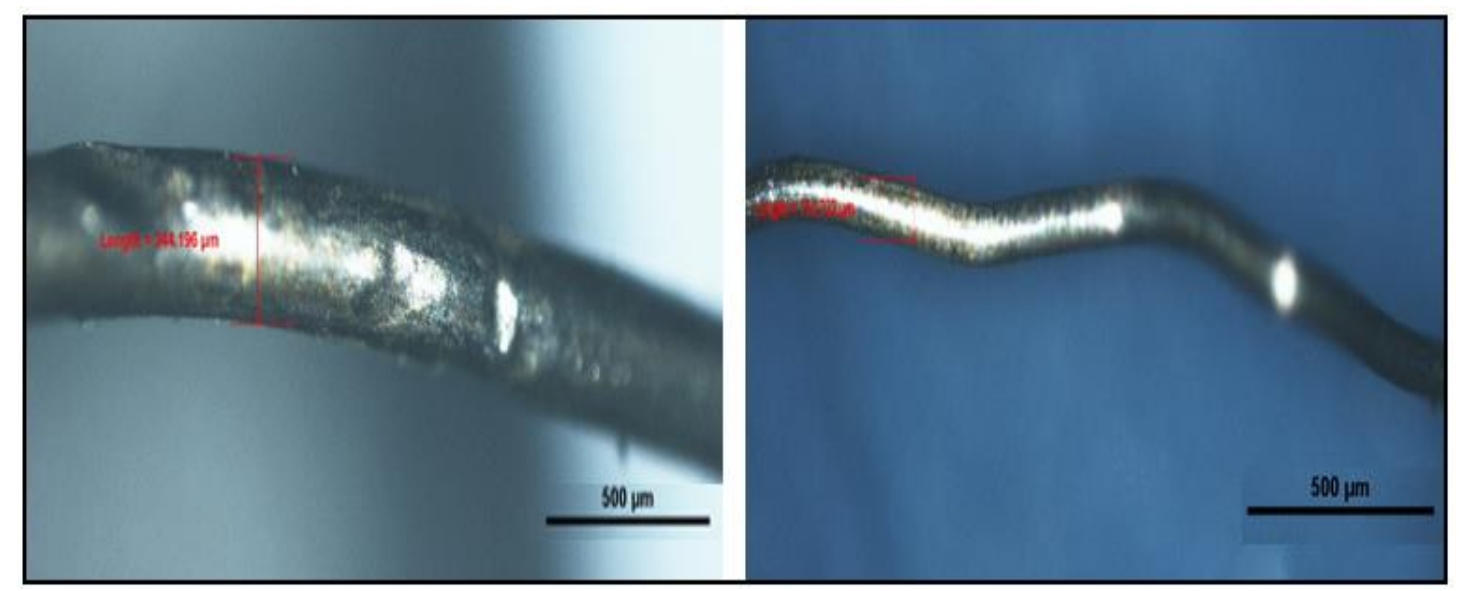

433

Figure 3 Optical microscope images of steel fibre

434 


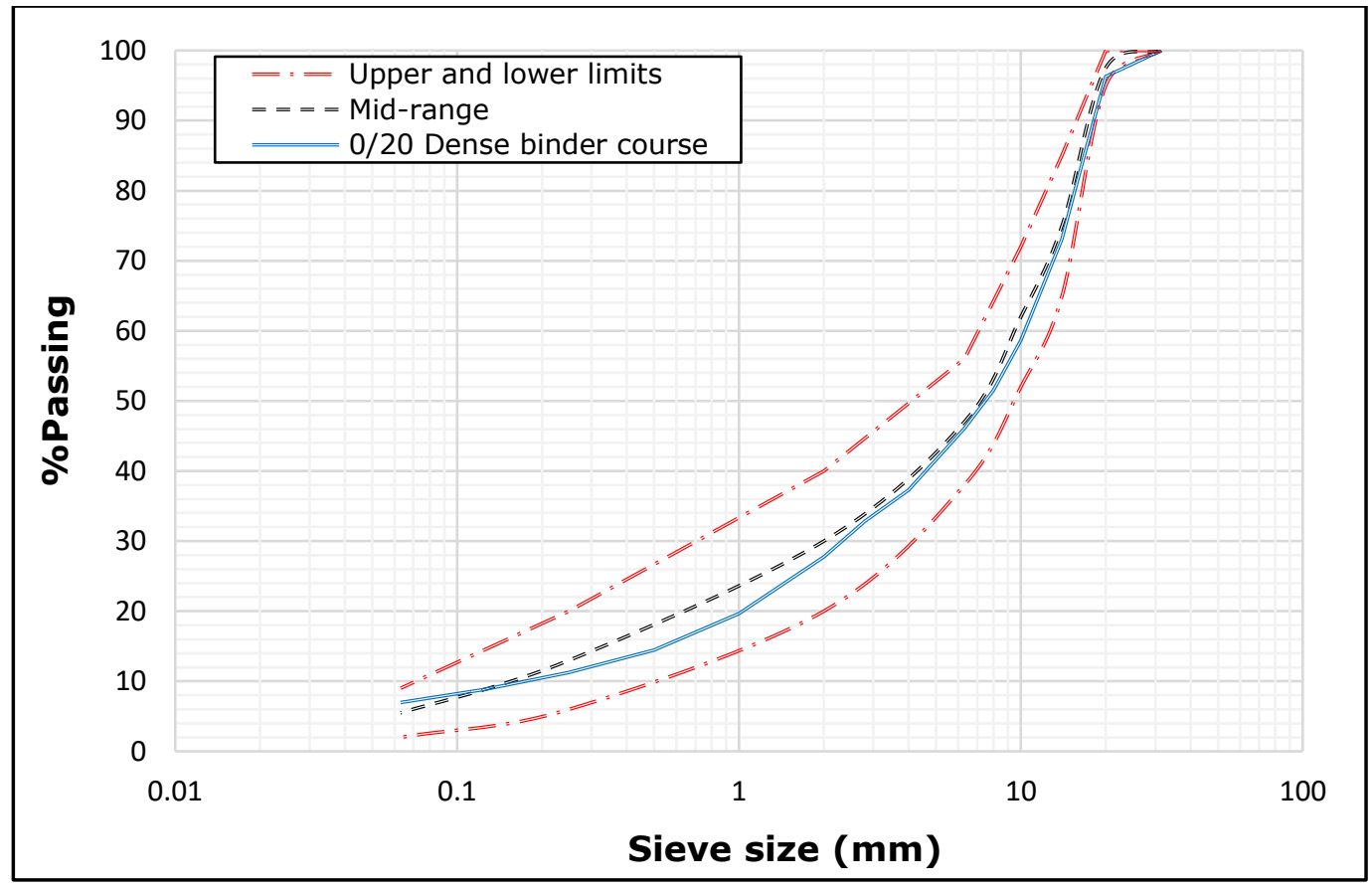

436

Figure 4 Gradation curve of 0/20 mm binder course DBM

437

438

439

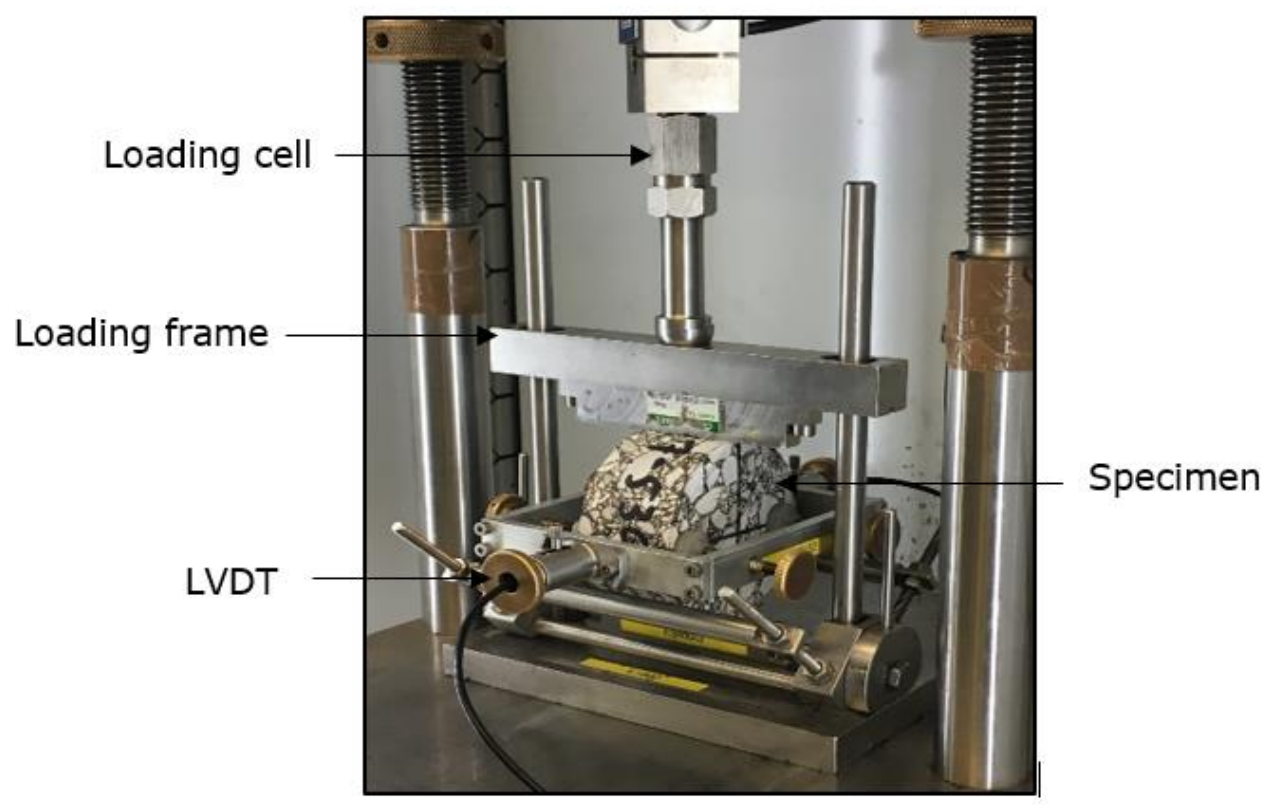

440

Figure 5 ITSM test configuration

441 
442

443

444

445

446

447

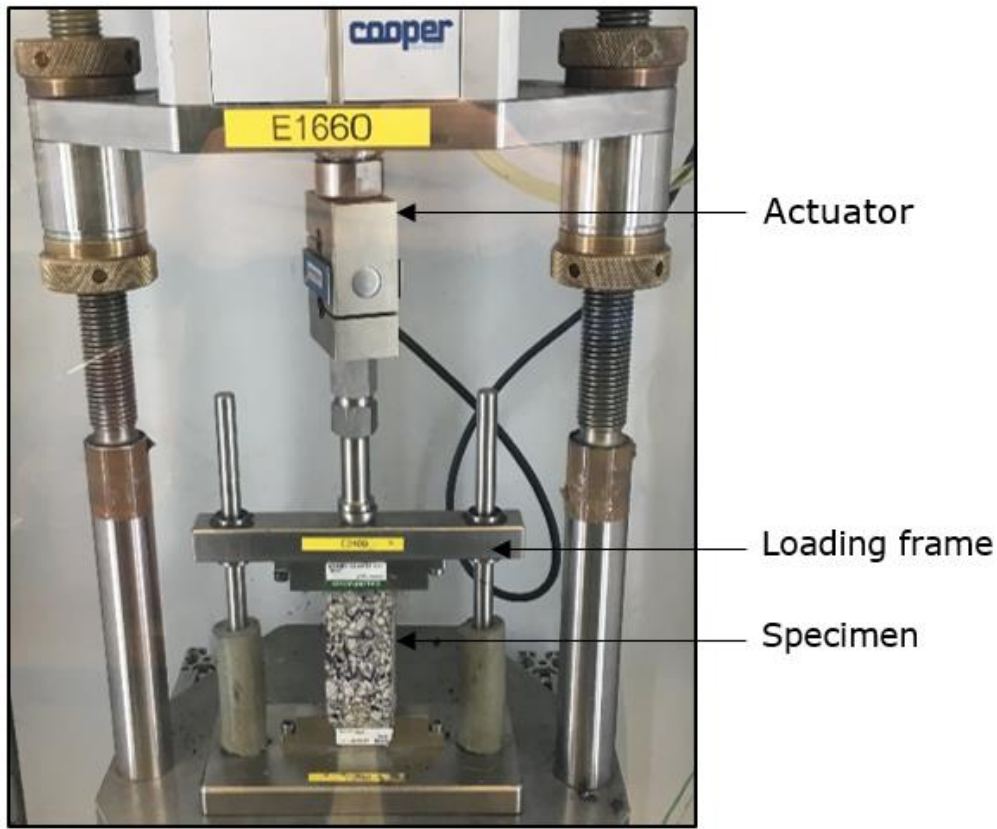

Figure 6 ITFT test configuration

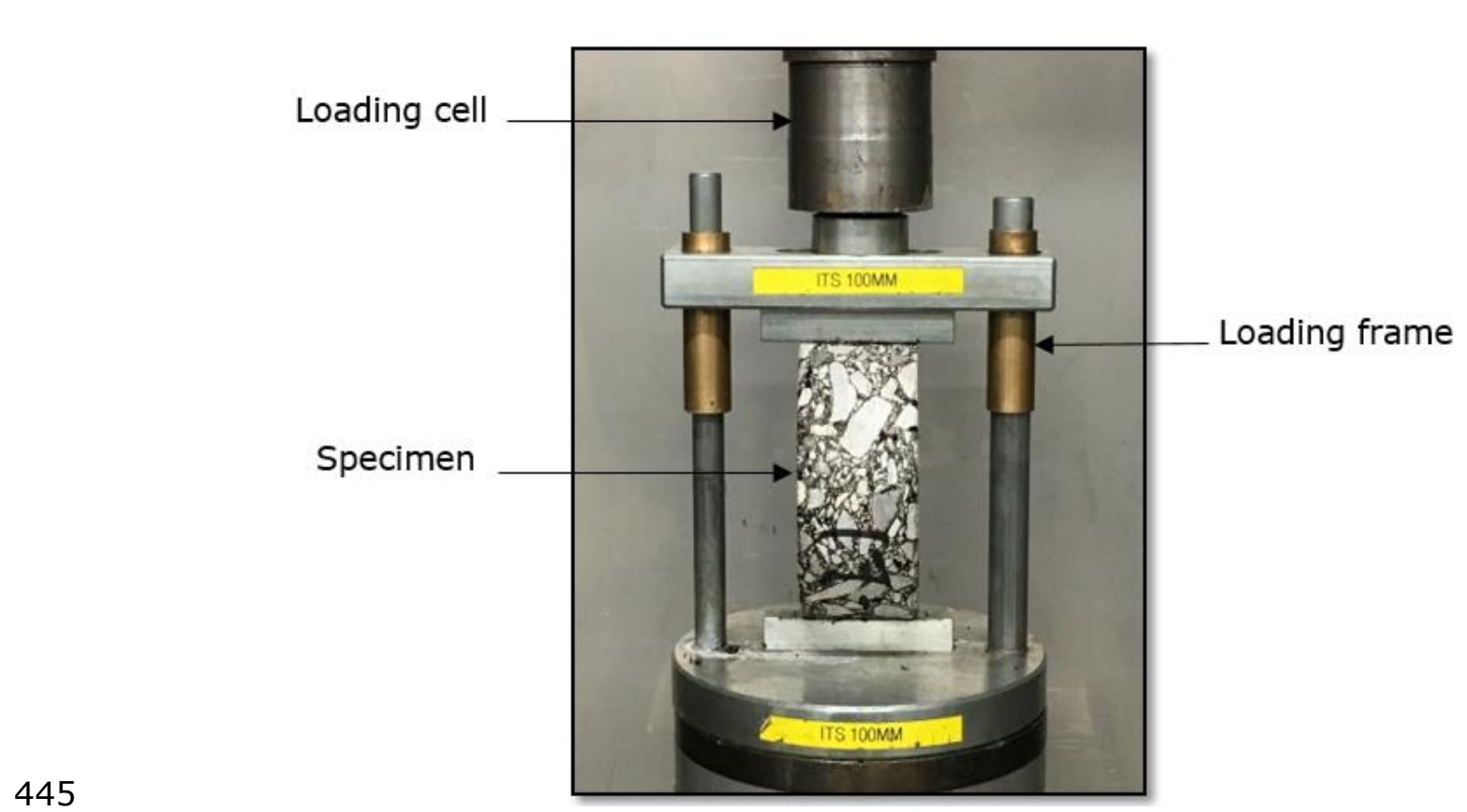

Figure 7 Experimental setup of ITS 
448

449

450

451

452

453

454

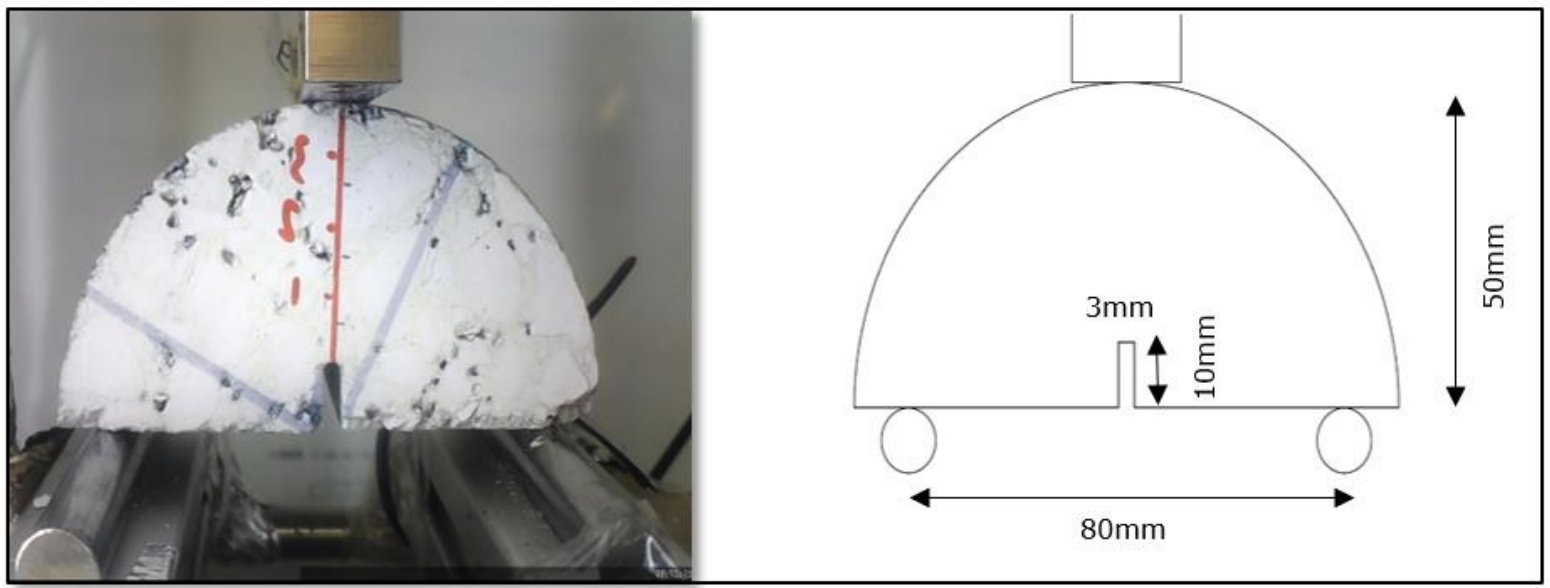

Figure 8 SCB test configuration
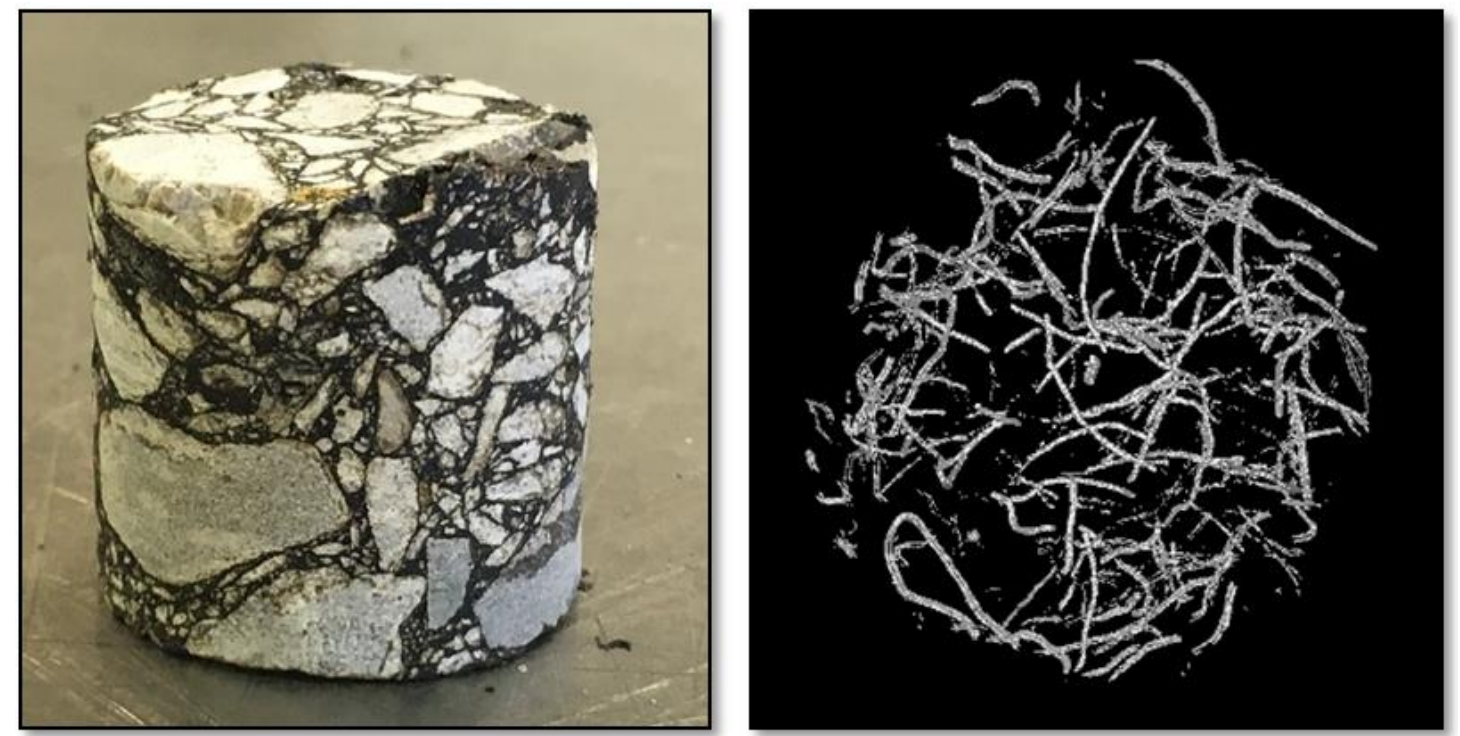

Figure 9 Three dimensional distribution of steel fibres inside asphalt mixture 
455

456

457

458

459

460

461

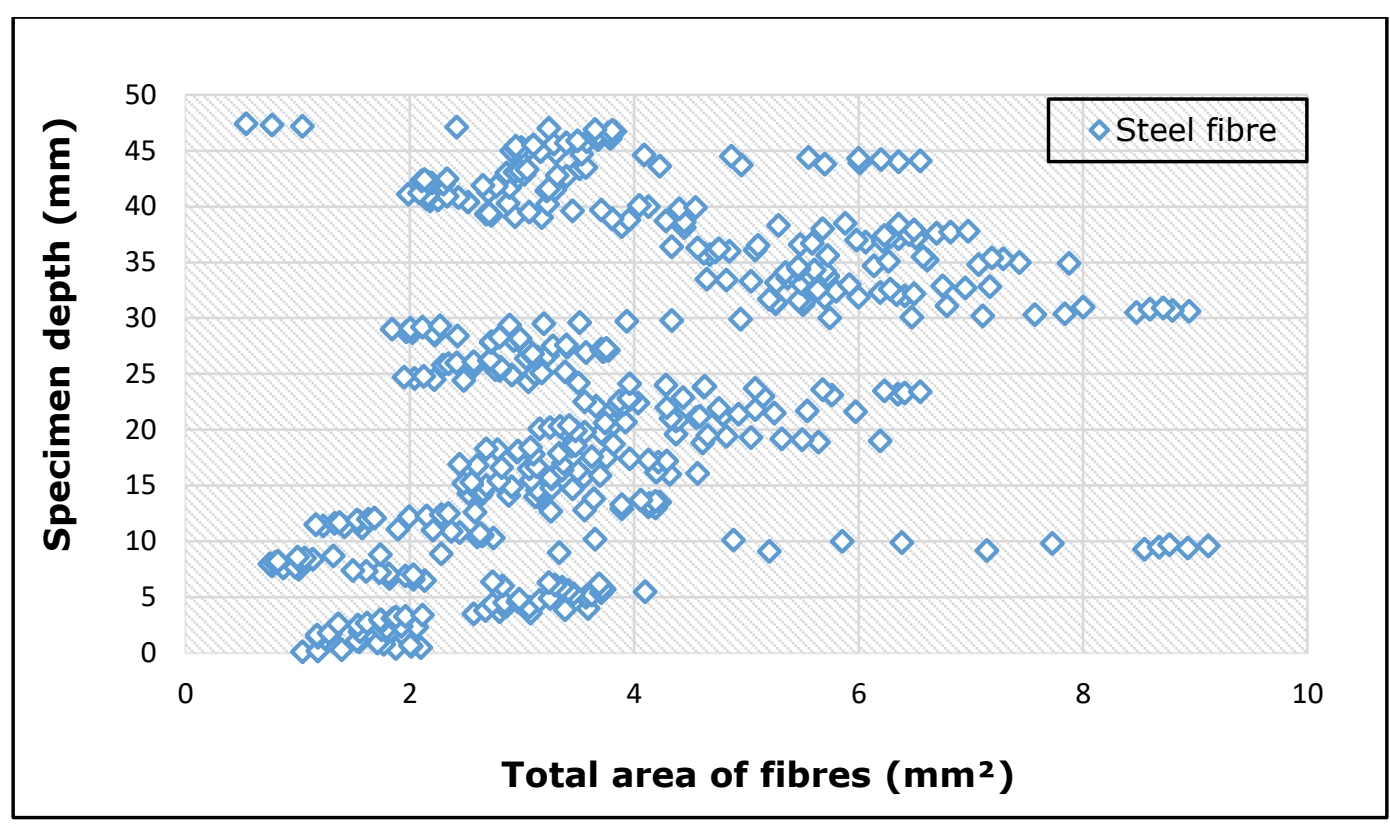

Figure 10 Total area of fibres along the specimen depth 

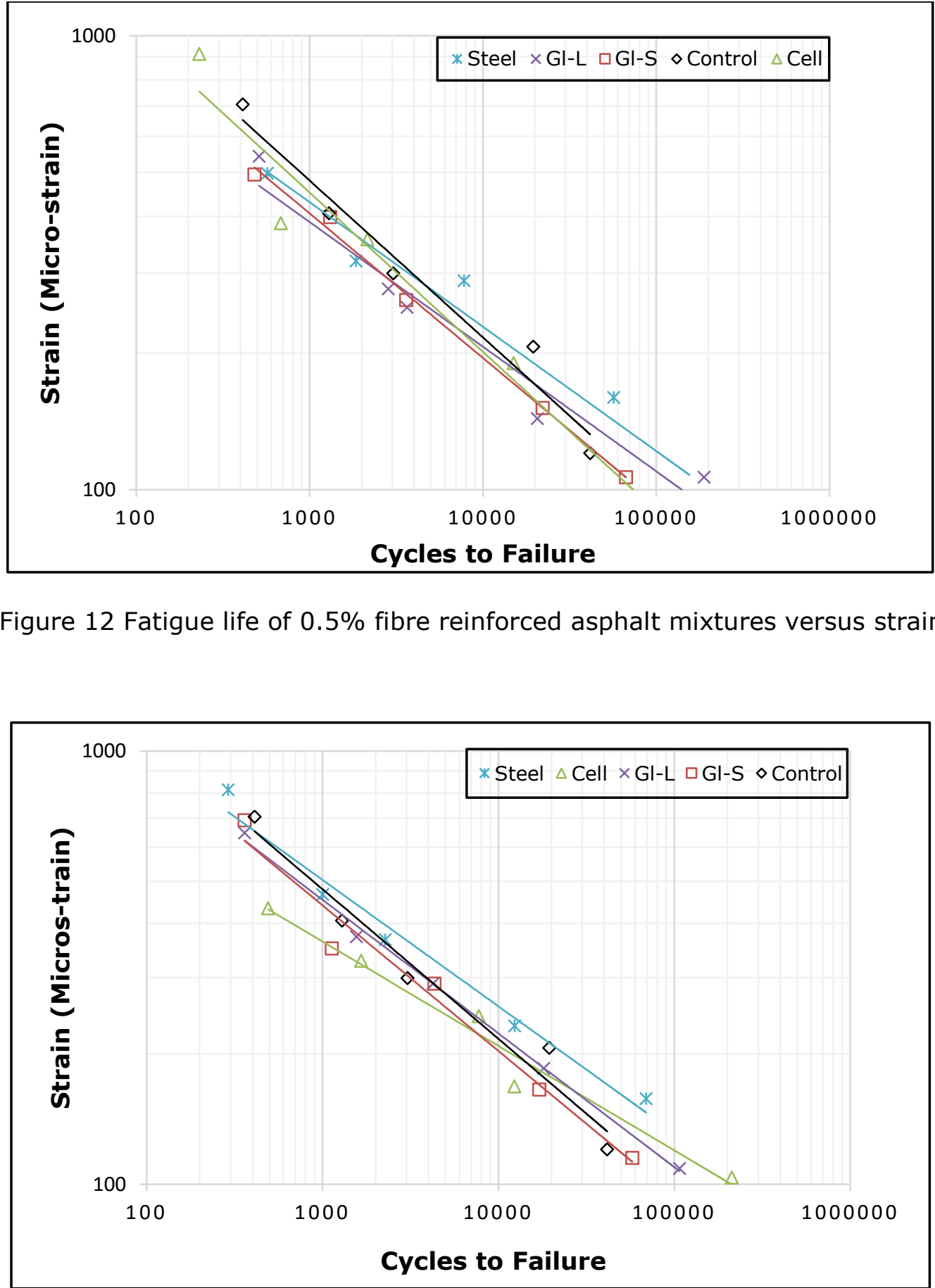

Figure 13 Fatigue life of $1.0 \%$ fibre reinforced asphalt mixtures versus strain 
473

474

475

476

477

478

479

480

481

482

483

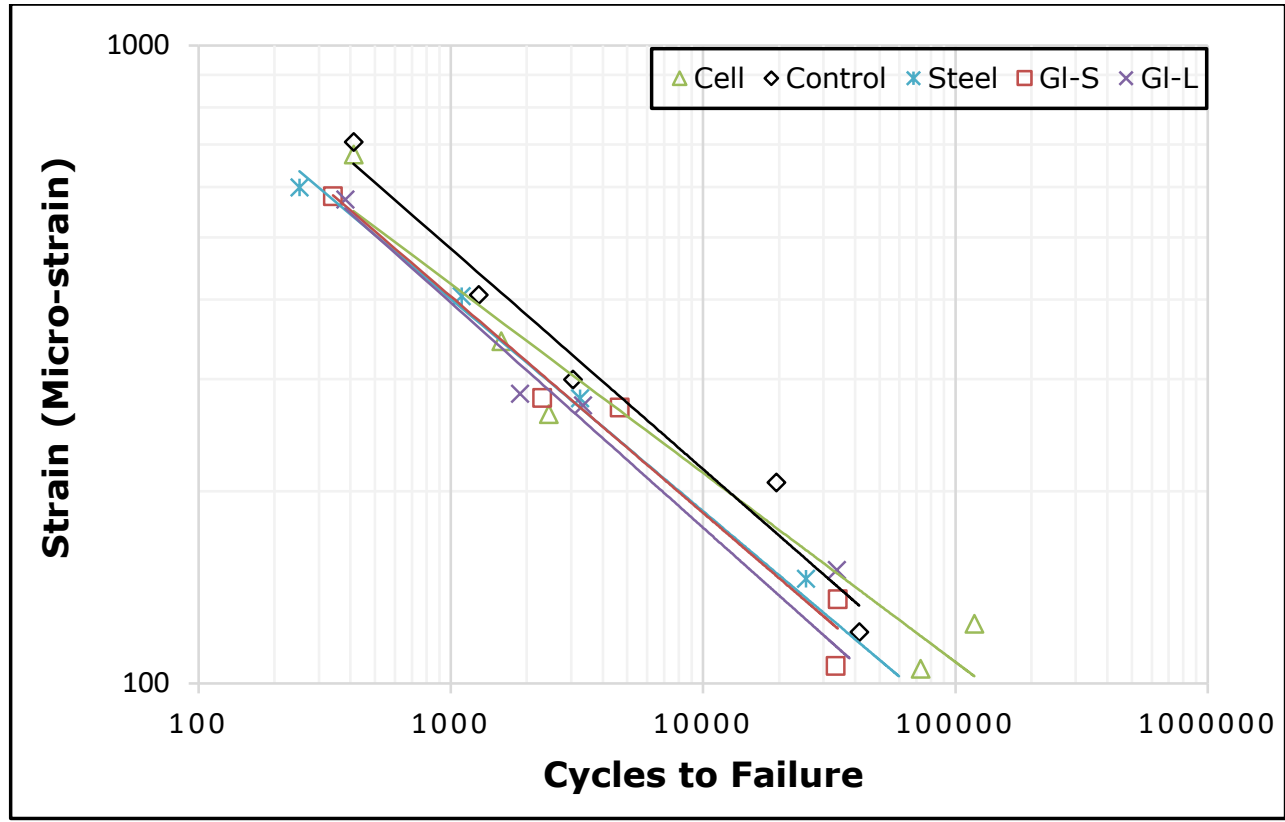

Figure 14 Fatigue life of $2.0 \%$ fibre reinforced asphalt mixtures versus strain 

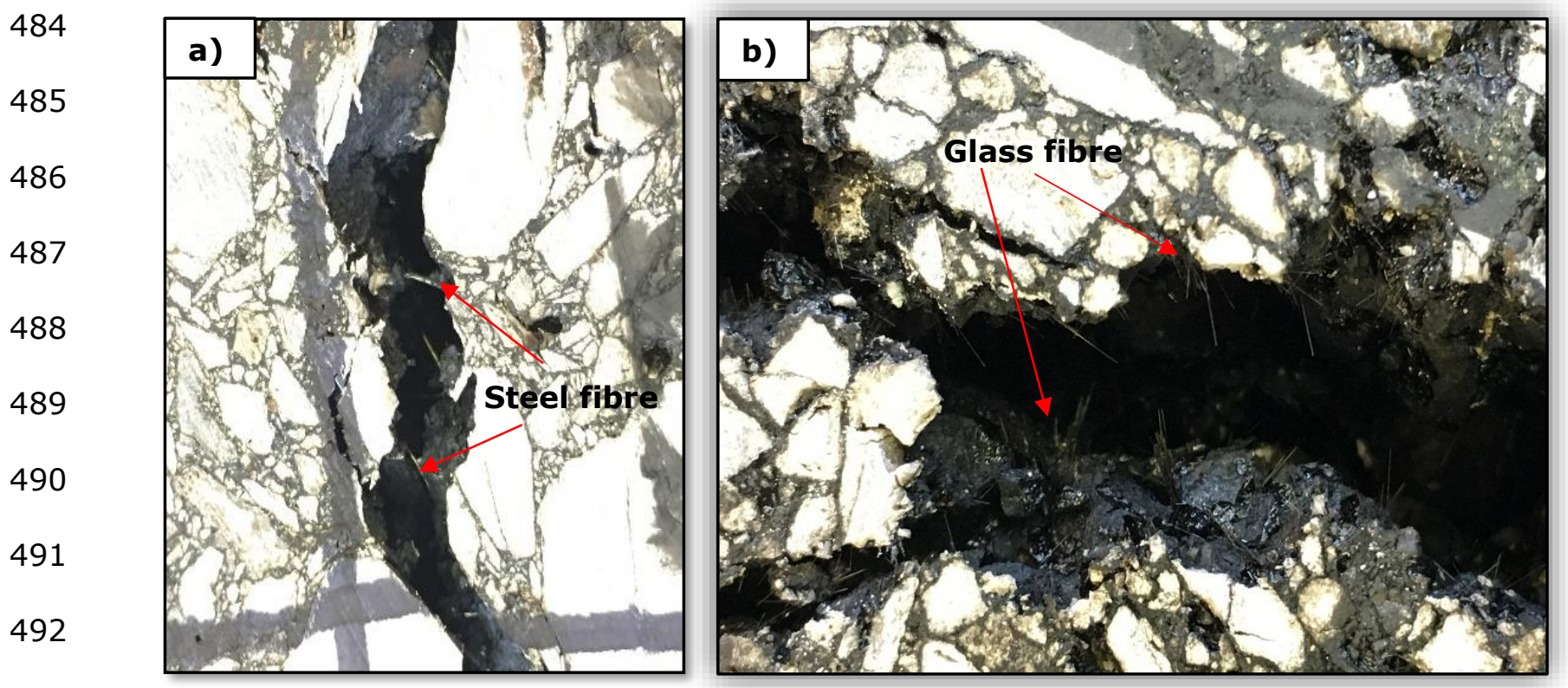

493

494

Figure 16 (a) steel, (b) glass fibre reinforced asphalt mixtures

495

496

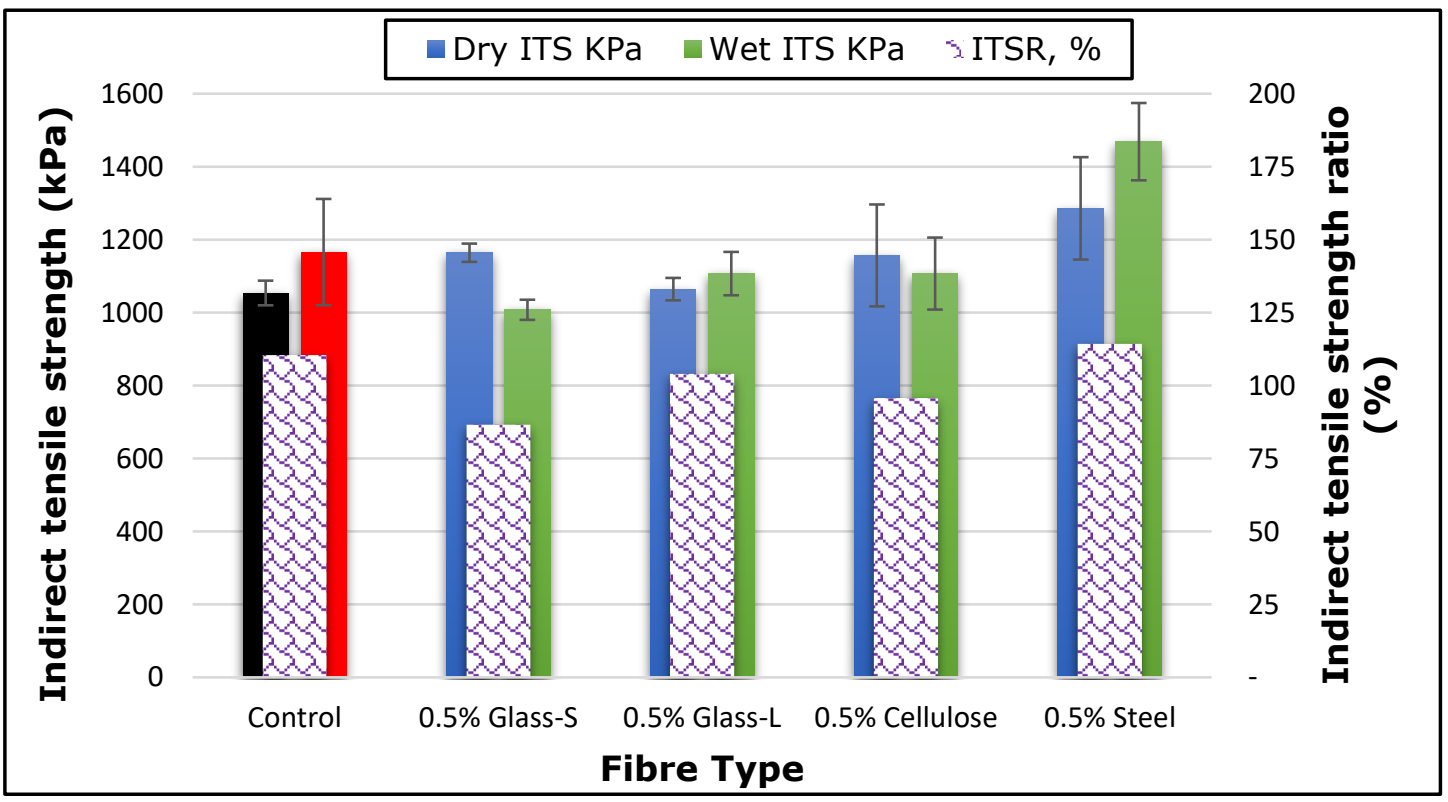

497 Figure 17 Moisture damage results of control and $0.5 \%$ fibre reinforced asphalt mixtures 498 


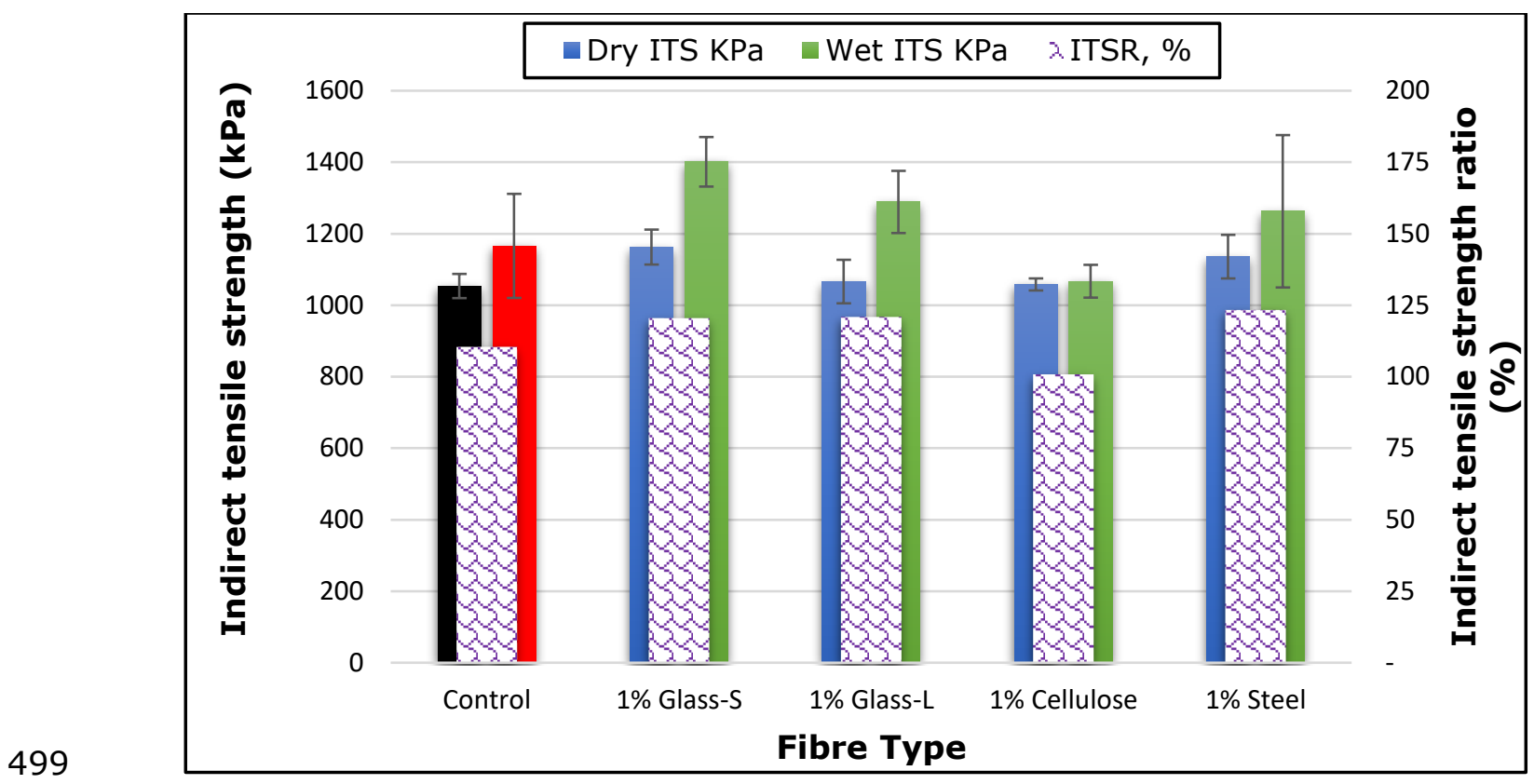

500 Figure 18 Moisture damage results of control and $1.0 \%$ fibre reinforced asphalt mixtures 501

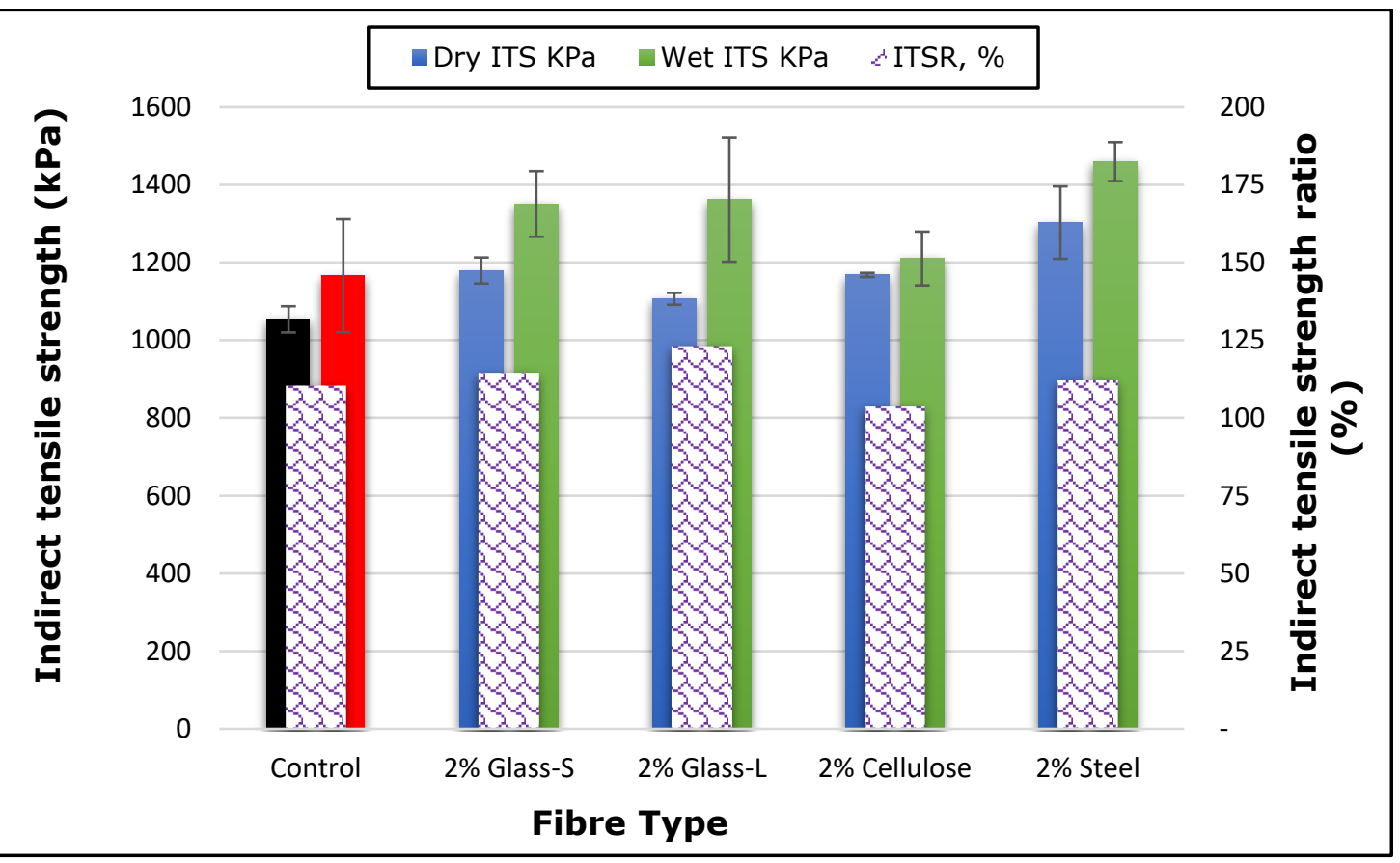

503 Figure 19 Moisture damage results of control and $2.0 \%$ fibre reinforced asphalt mixtures 

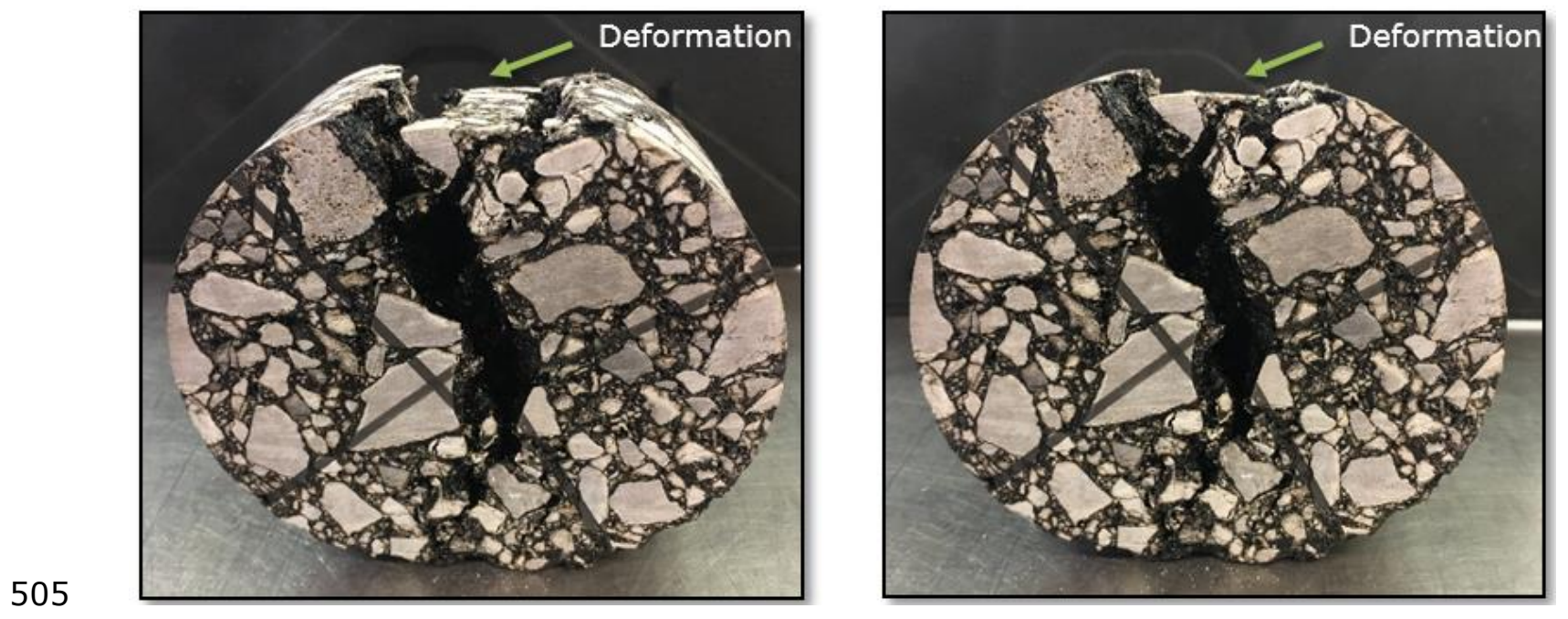

506

Figure 20 Asphalt mixture samples after ITS test

507

508

509

510

511

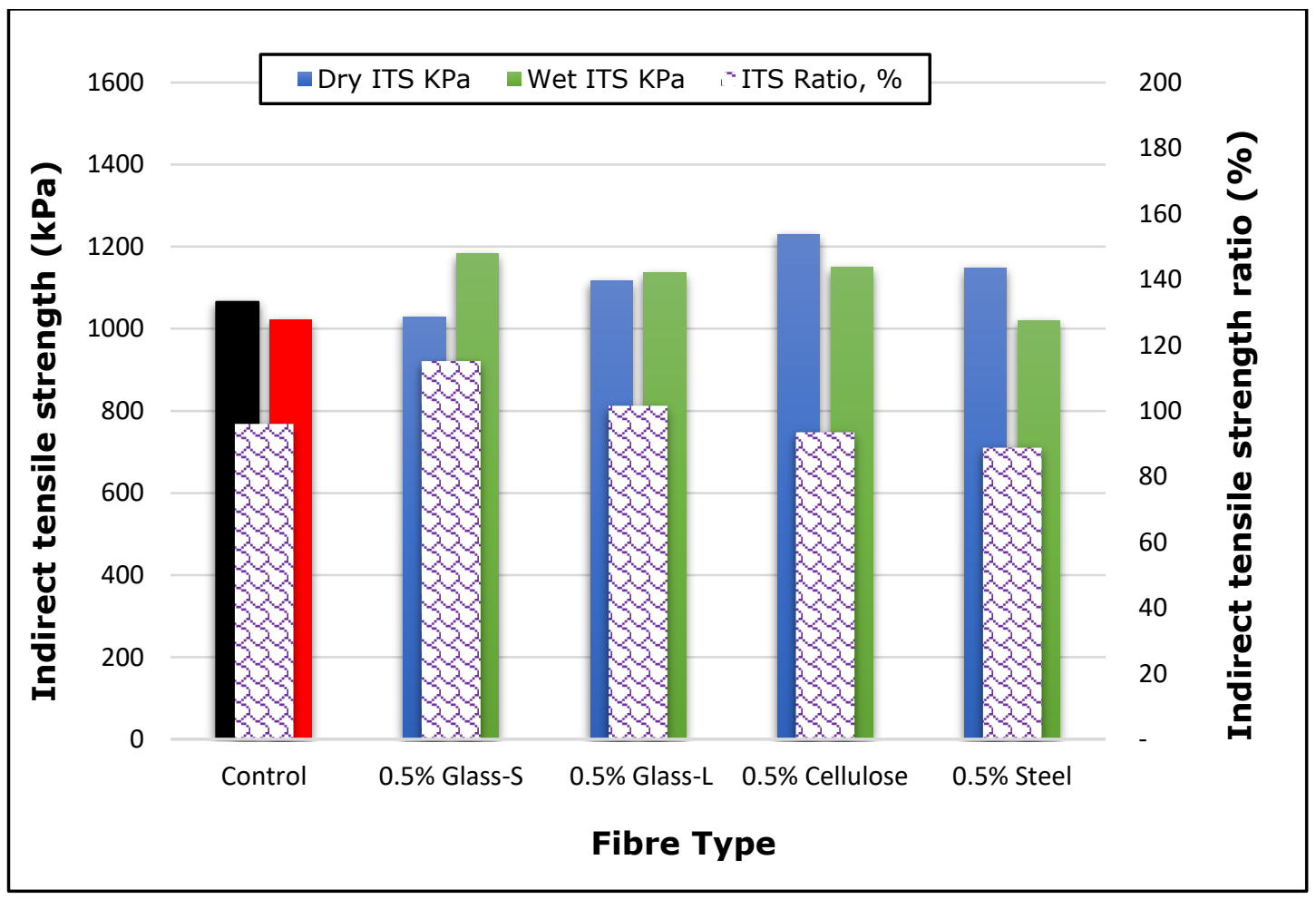

Figure 21 Moisture damage results of control and $0.5 \%$ fibre reinforced asphalt mixtures after RLAT test 


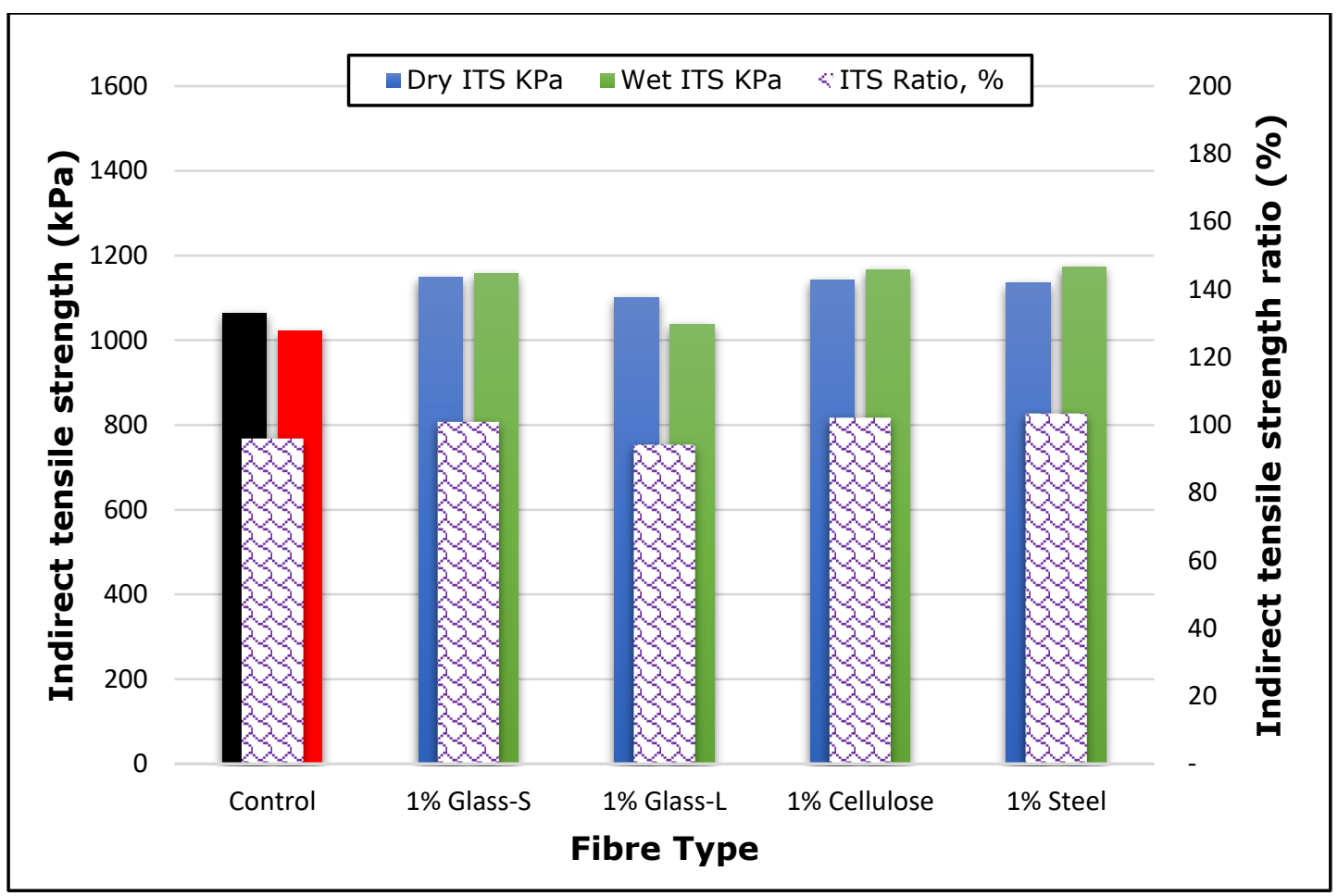

513 Figure 22 Moisture damage results of control and $1.0 \%$ fibre reinforced asphalt mixtures 514 after RLAT test

515

516

517

518

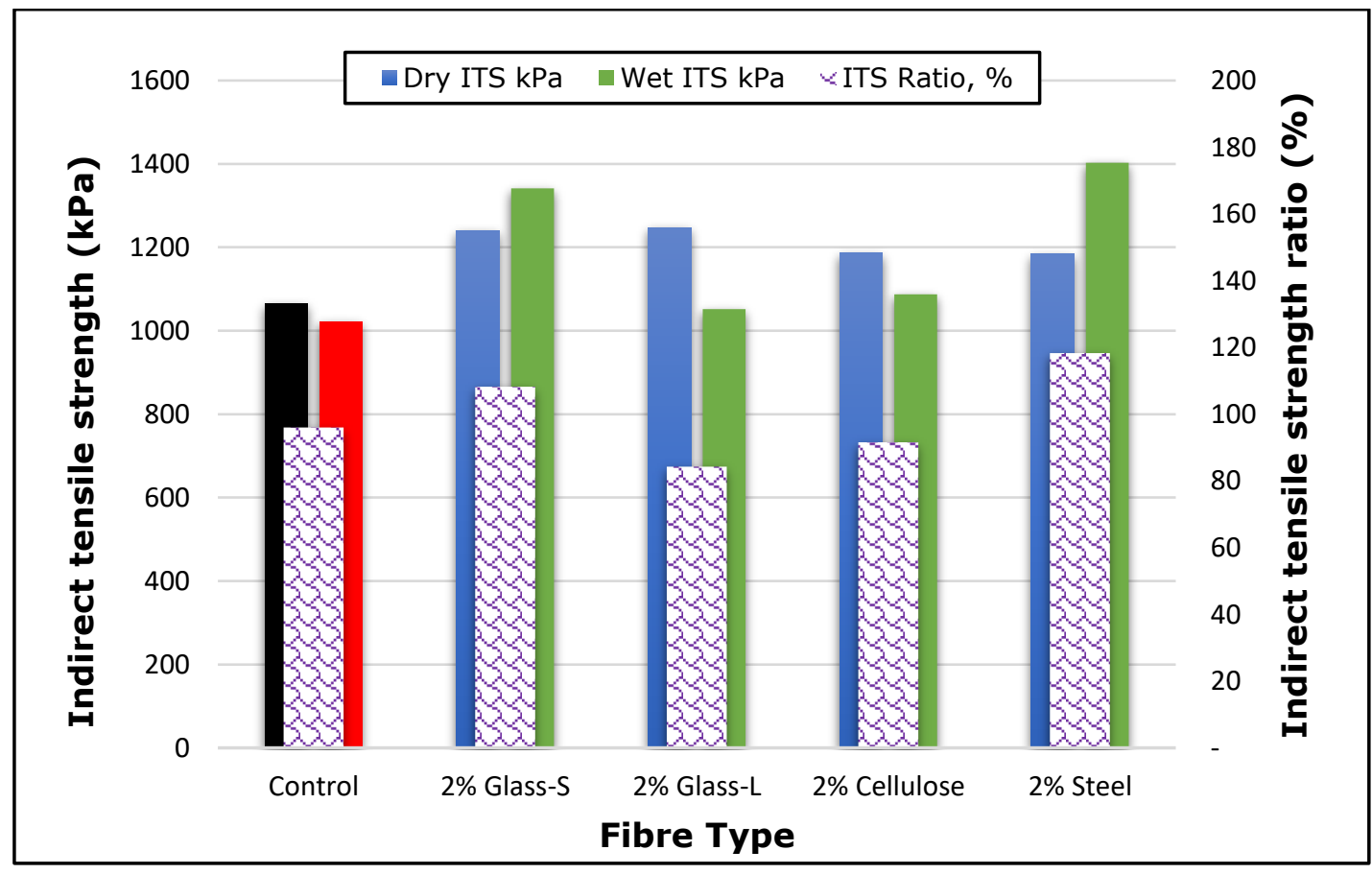

Figure 23 Moisture damage results of control and $2.0 \%$ fibre reinforced asphalt mixtures after RLAT test 


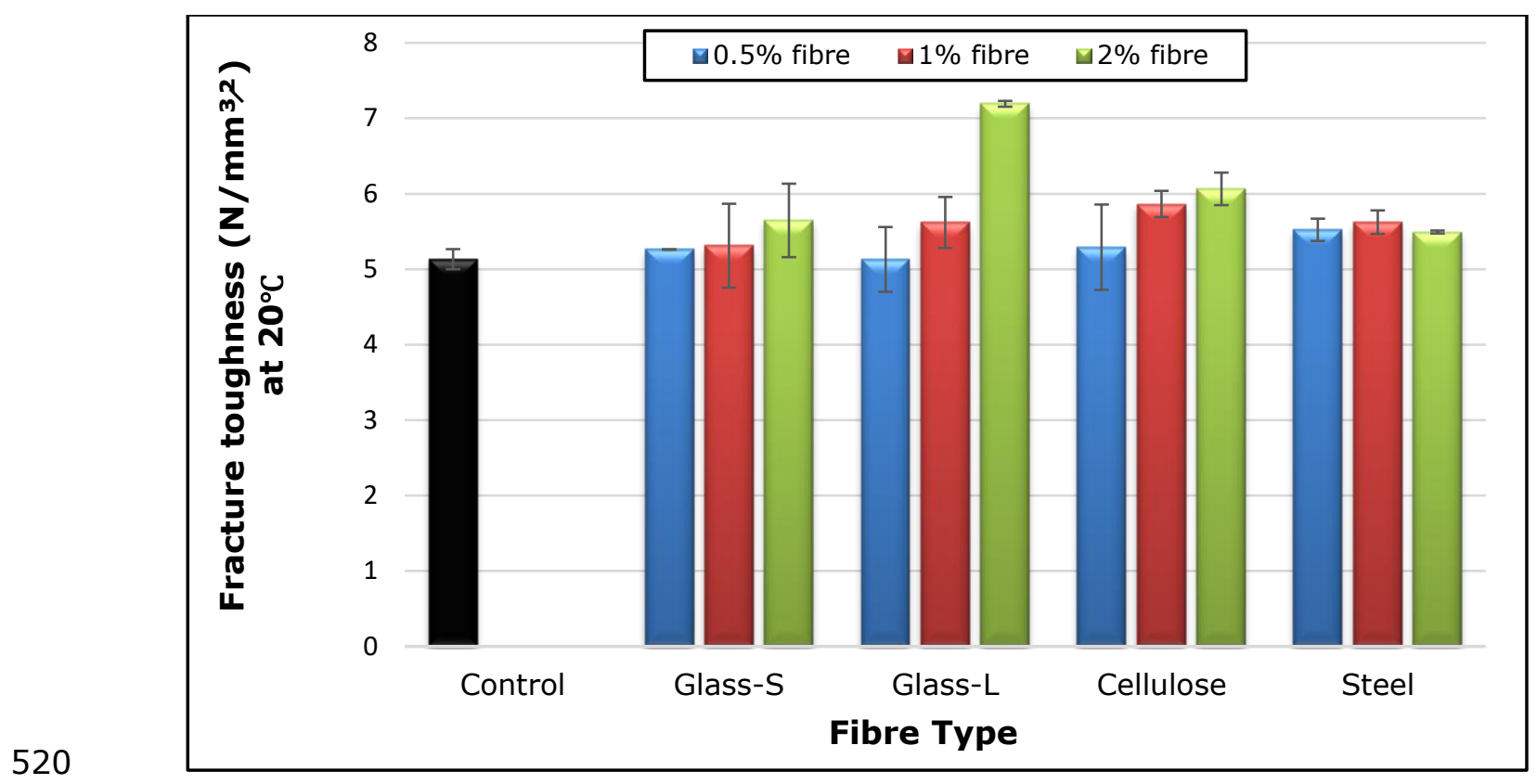

521 Figure 24 Fracture toughness of control and fibre reinforced asphalt mixtures at $20^{\circ} \mathrm{C}$

522

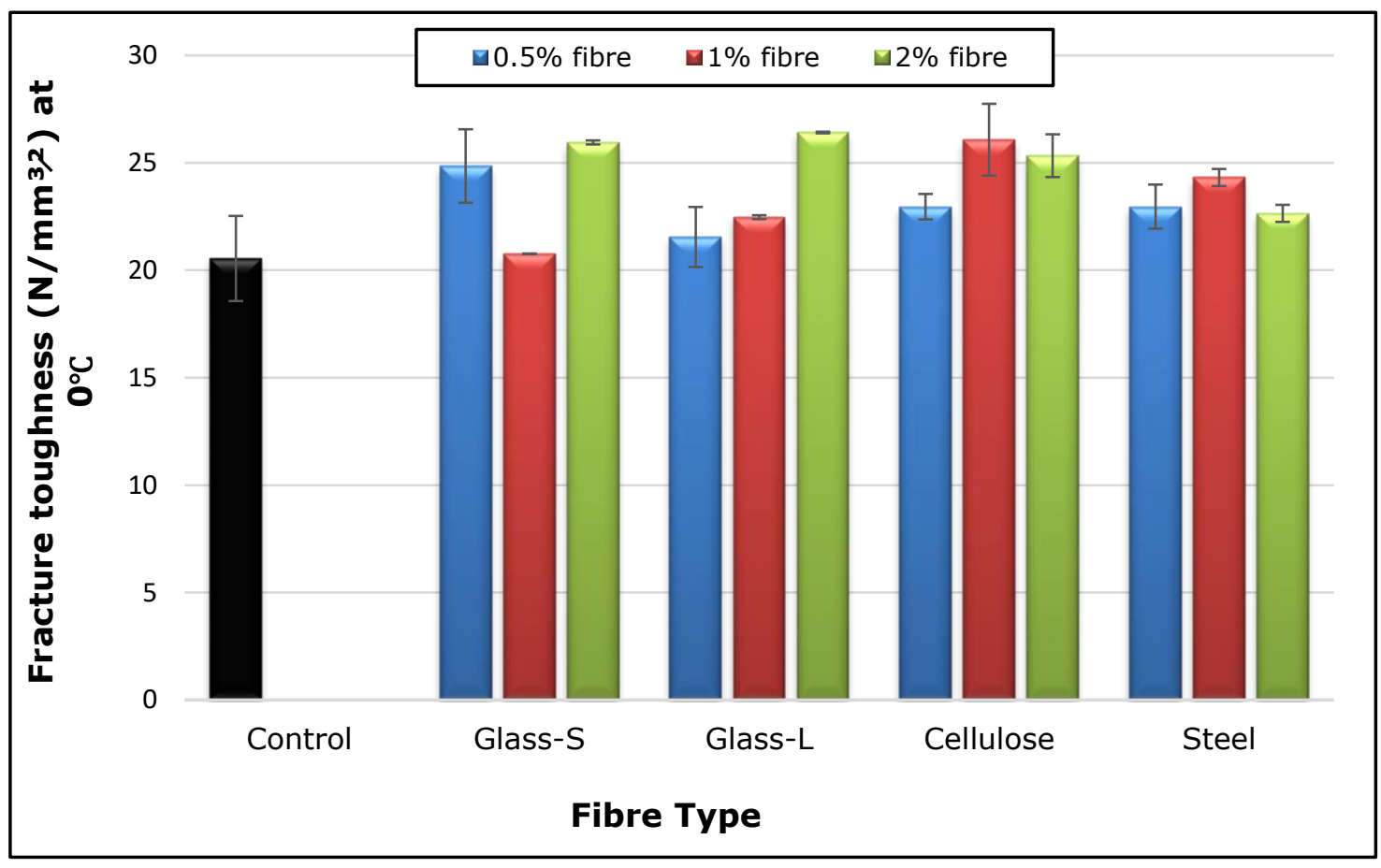

524 Figure 25 Fracture toughness of control and fibre reinforced asphalt mixtures at $0^{\circ} \mathrm{C}$ 


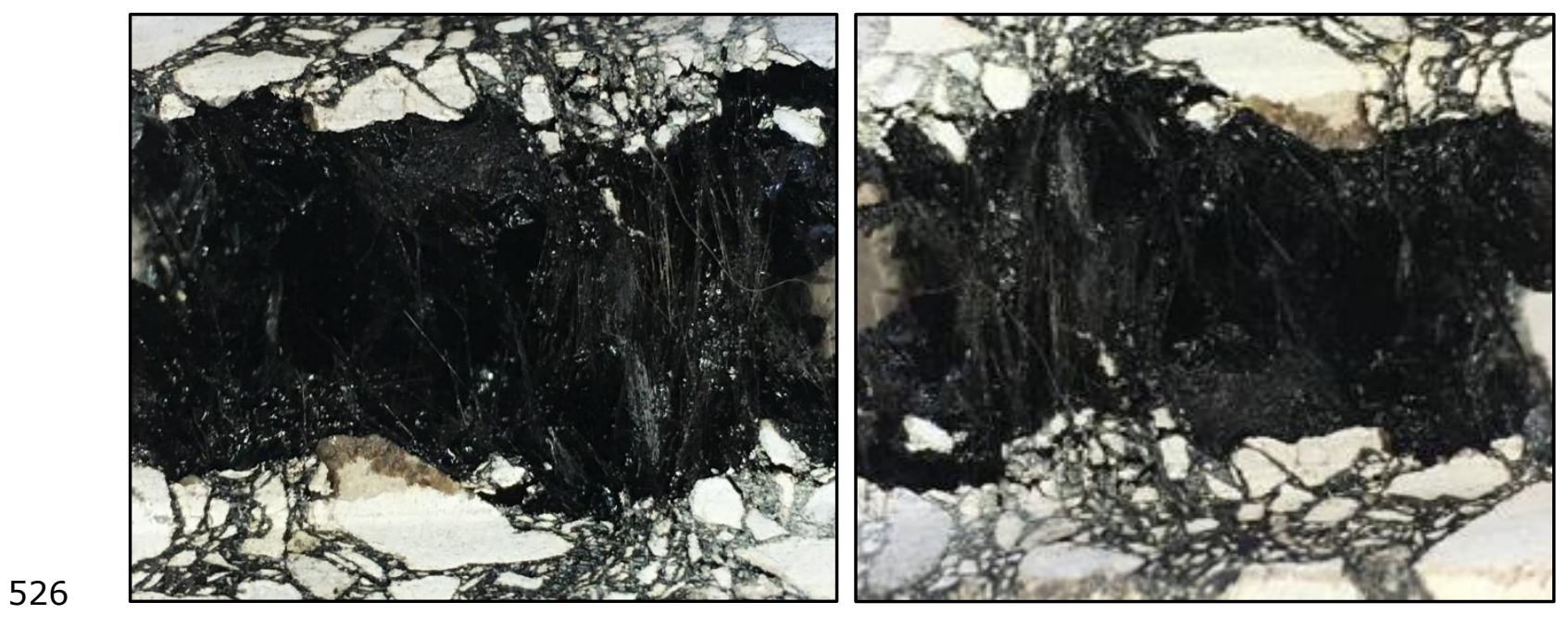

527 Figure 26 Long glass fibres observed at the notch area of asphalt mixture sample

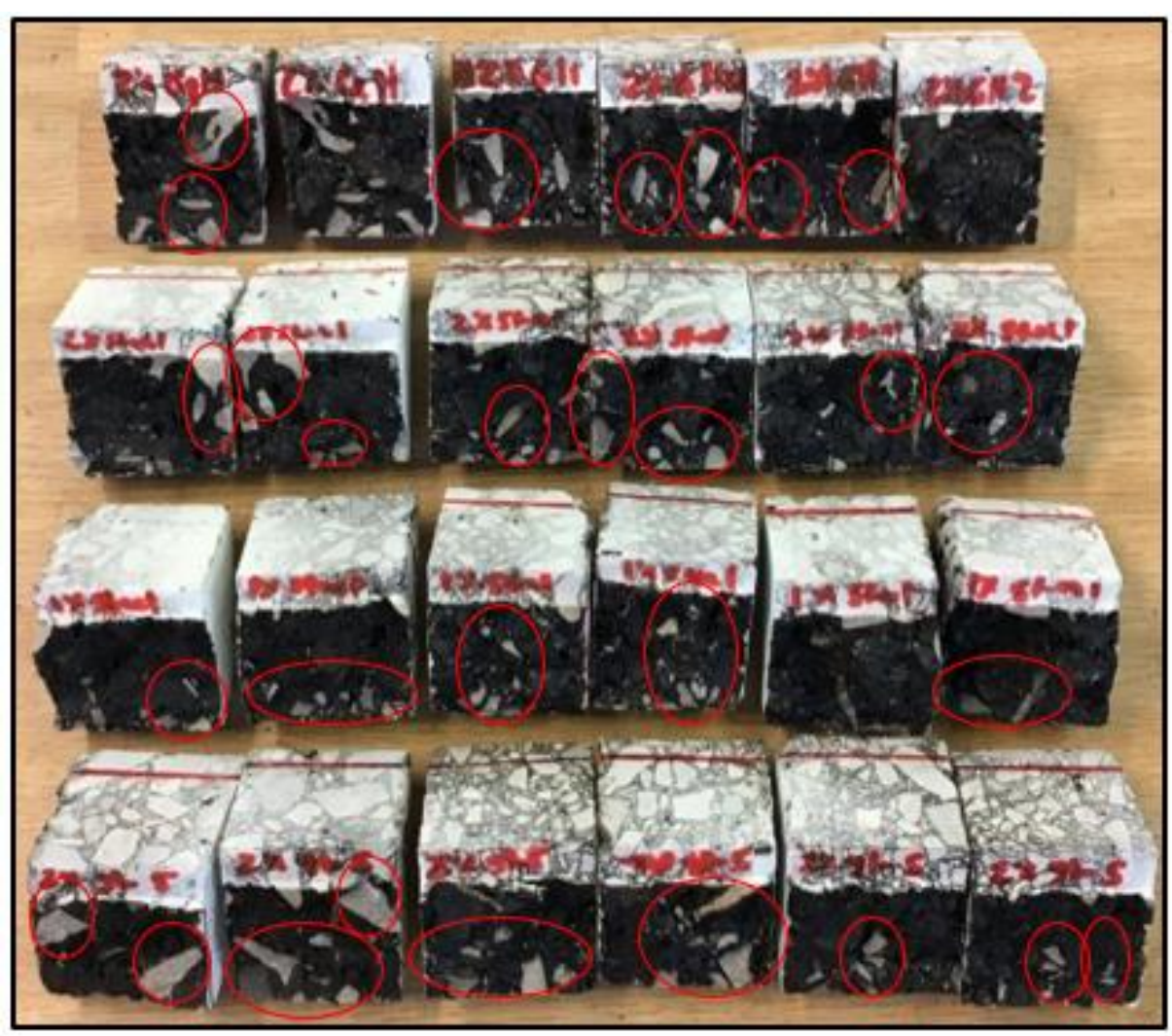

530 Figure 27 Fracture face at $0^{\circ} \mathrm{C}$ test temperature (red circles show aggregate fracture) 


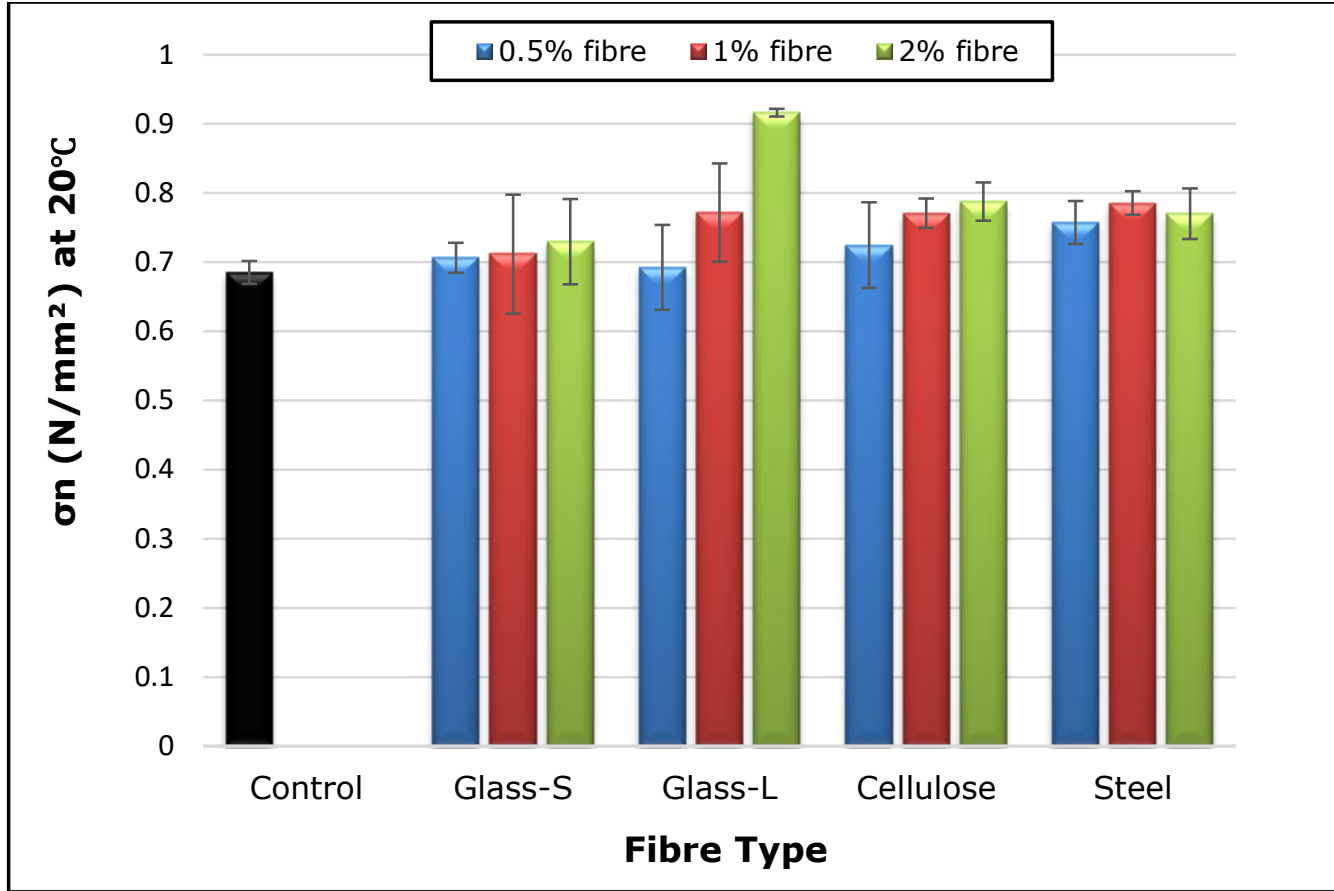

Figure 28 Maximum stress of control and fibre reinforced asphalt mixtures at $20^{\circ} \mathrm{C}$

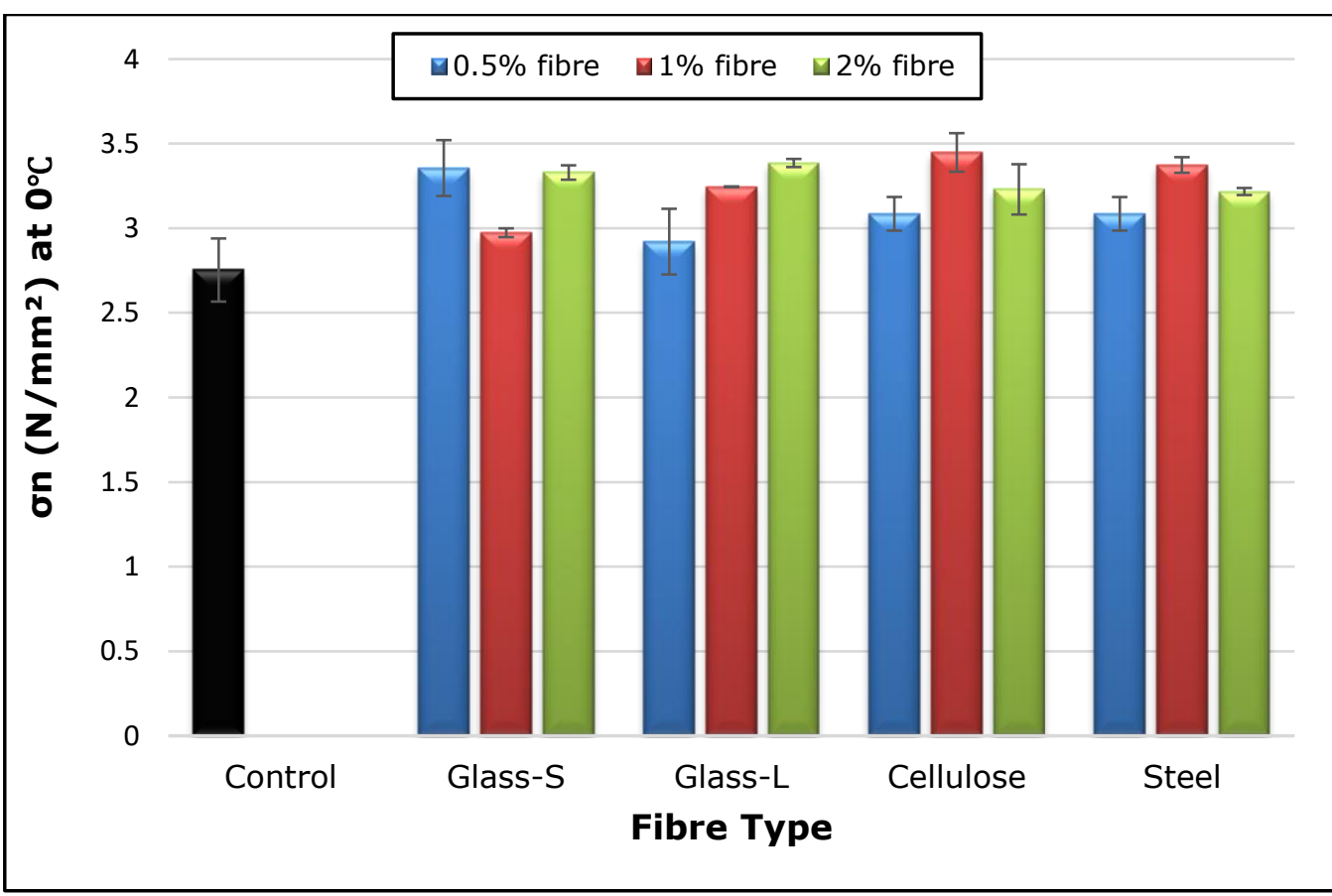

Figure 29 Maximum stress of control and fibre reinforced asphalt mixtures at $0^{\circ} \mathrm{C}$ 
537

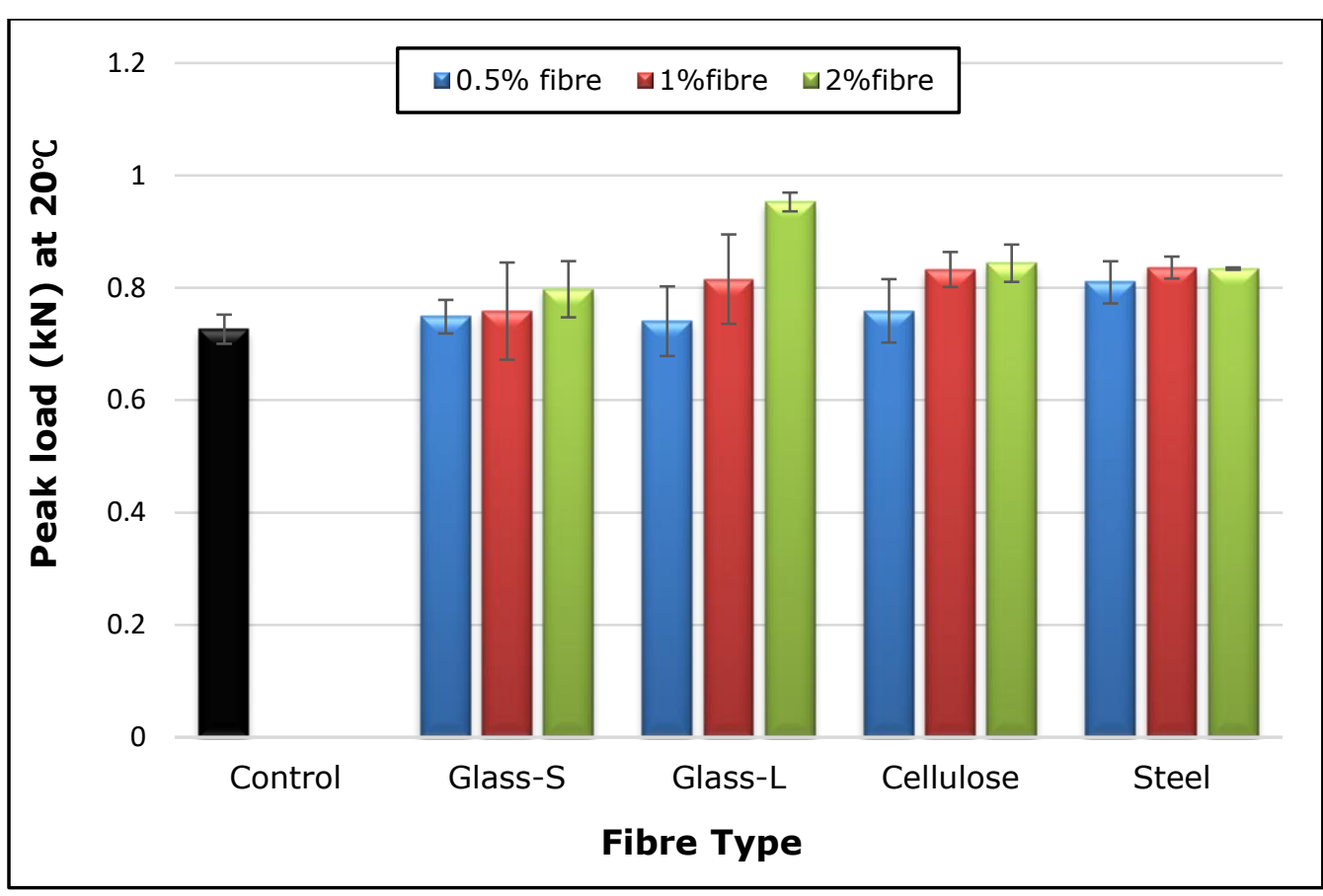

Figure 30 Peak load of control and fibre reinforced asphalt mixtures at $20^{\circ} \mathrm{C}$

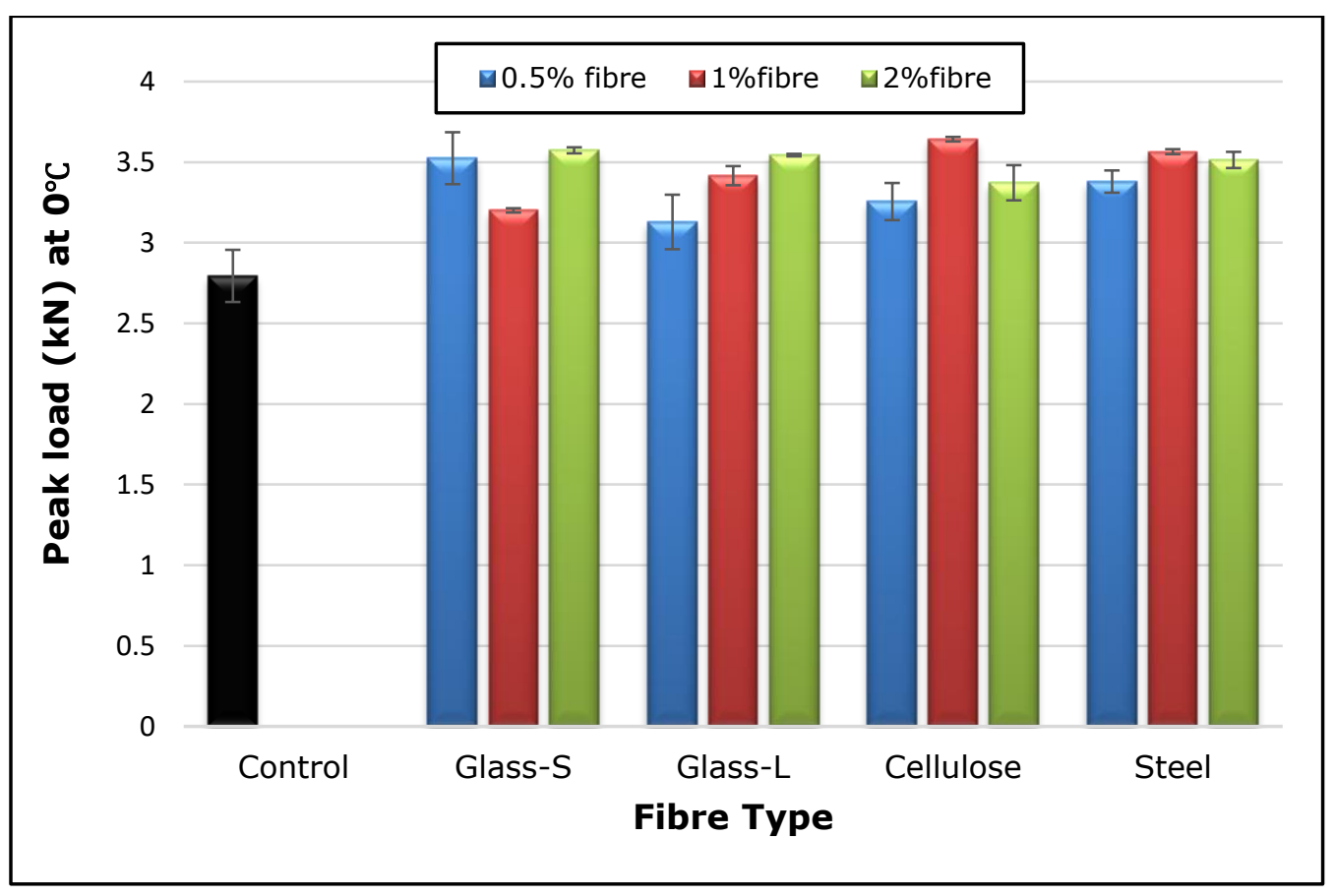

Figure 31 Peak load of control and fibre reinforced asphalt mixtures at $0^{\circ} \mathrm{C}$ 


\section{References}

547 [1] J. Kim, C. Koh, Development of a predictive system for estimating fatigue life of asphalt

548 mixtures using the indirect tensile test, Journal of Transportation Engineering 138(12)

549 (2012) 1530-1540.

550 [2] F. Perez-Jimenez, R. Botella, K.-H. Moon, M. Marasteanu, Effect of load application rate and temperature on the fracture energy of asphalt mixtures. Fénix and semi-circular bending tests, Construction and Building Materials 48 (2013) 1067-1071.

553 [3] Y. Cheng, J. Tao, Y. Jiao, Q. Guo, C. Li, Influence of diatomite and mineral powder on thermal oxidative ageing properties of asphalt, Advances in Materials Science and Engineering 2015 (2015).

[4] S. Oda, J.L. Fernandes Jr, J.S. Ildefonso, Analysis of use of natural fibers and asphalt rubber binder in discontinuous asphalt mixtures, Construction and Building Materials 26(1)

558 (2012) 13-20.

559

560

561

562

563

564

565

566

567

568

569

570

571

572

573

574

575

576

577

578

579

580

581

582

583

584

585
[5] X. Qin, A. Shen, Y. Guo, Experimental study on road performance of basalt fiber reinforced Bitumen mastics, Journal of Building Materials 19(4) (2016) 660-664.

[6] Y. Kim, T.-S. Park, Reinforcement of recycled foamed asphalt using short polypropylene fibers, Advances in Materials Science and Engineering 2013 (2013).

[7] T.R. Herraiz, J.I.R. Herraiz, L.M. Domingo, F.C. Domingo, Posidonia oceanica used as a new natural fibre to enhance the performance of asphalt mixtures, Construction and Building Materials 102 (2016) 601-612.

[8] P.J. Yoo, K.-H. Kim, Thermo-plastic fiber's reinforcing effect on hot-mix asphalt concrete mixture, Construction and Building Materials 59 (2014) 136-143.

[9] S. Wu, Q. Ye, N. Li, H. Yue, Effects of fibers on the dynamic properties of asphalt mixtures, Journal of Wuhan University of Technology-Mater. Sci. Ed. 22(4) (2007) 733736.

[10] B.J. Putman, S.N. Amirkhanian, Utilization of waste fibers in stone matrix asphalt mixtures

Resources, conservation and recycling 42(3) (2004) 265-274.

[11] S.J. Lee, J.P. Rust, H. Hamouda, Y.R. Kim, R.H. Borden, Fatigue cracking resistance of fiber-reinforced asphalt concrete, Textile Research Journal 75(2) (2005) 123-128.

[12] BS EN 1426, Bitumen and bituminous binders-determination of needle penetration, British Standard and European Committee, London, United Kingdom, 2007.

[13] BS 4987-1, Coated macadam (asphalt concrete) for roads and other paved areas, Specification for constituent materials and for mixtures, British Standard, Standards Policy and Strategy Committee, London, United Kingdom, 2005.

[14] BS EN 12697-35, Bituminous mixtures - Test methods, Part 35: Laboratory mixing, British Standard and European Committee, London, United Kingdom, 2016.

[15] BS EN 12697-33, Bituminous mixtures -Test methods for hot mix asphalt, Part 33: Specimen prepared by roller compactor, British Standard and European Committee, London, United Kingdom, 2003. 
586 [16] A. Mahrez, M.R. Karim, H.Y.b. Katman, Fatigue and deformation properties of glass

587 fiber reinforced bituminous mixes, Journal of the Eastern Asia Society for Transportation

588 Studies 6 (2005) 997-1007.

589 [17] M.A. Cleven, Investigation of the properties of carbon fiber modified asphalt mixtures, 590 Michigan Technological University, 2000.

591 [18] C. Alvarado, E. Mahmoud, I. Abdallah, E. Masad, S. Nazarian, R. Langford, V. Tandon, 592 J. Button, Feasibility of quantifying the role of coarse aggregate strength on resistance to 593 load in HMA, TxDOT Project No. 0-5268 and Research Report No. 0-5268 (2007).

594 [19] R. Xiong, J. Fang, A. Xu, B. Guan, Z. Liu, Laboratory investigation on the brucite fiber 595 reinforced asphalt binder and asphalt concrete, Construction and Building Materials 83 596 (2015) 44-52.

597 [20] H. Chen, Q. Xu, Experimental study of fibers in stabilizing and reinforcing asphalt 598 binder, Fuel 89(7) (2010) 1616-1622.

599 [21] M. Mohammed, T. Parry, J. Grenfell, Influence of fibres on rheological properties and 600 toughness of bituminous binder, Construction and Building Materials 163 (2018) 901-911.

601 [22] B.R. Wiljanen, The pavement performance and life-cycle cost impacts of carbon fiber 602 modified hot mix asphalt, Michigan Technological University, 2003.

603 [23] M.J. Dennis, Industrial computed tomography, General Electric, NDE System and 604 Service (1997).

605 [24] E. Masad, B. Muhunthan, N. Shashidhar, T. Harman, Internal structure 606 characterization of asphalt concrete using image analysis, Journal of computing in civil 607 engineering 13(2) (1999) 88-95.

608 [25] BS EN 12697-26, Bituminous mixtures: Test methods for hot mix asphalt, Part 26: 609 Stiffness, British Standard and European Committee London, United Kingdom, 2012.

610 [26] Draft BS, DD ABF Method for the determination of the fatigue characteristics of 611 bituminous mixtures using indirect tensile fatigue British Standard, London, United 612 Kingdom, 2003.

613 [27] J.M. Read, A.C. Collop, Practical fatigue characterization of bituminous paving 614 mixture, Journal of the Association of Asphalt Paving Technologists 66 (1997).

615 [28] Draft BS EN 12697-24 Bituminous mixtures - Test methods - Part 24: Resistance to 616 fatigue Indirect tensile test on cylindrical shaped specimens, British Standard and 617 European Standard London, United Kingdom, 2015.

618 [29] BS EN 12697-23, Bituminous mixtures - Test methods Part 23: Determination of the 619 indirect tensile strength of bituminous specimens British Standard and European 620 Committee, London, United Kingdom, 2017.

621 [30] BS EN 12697-12, Part 12: Determination of the water sensitivity of bituminous 622 specimens, British Standard and European Committee London, United Kingdom, 2003.

623 [31] BS EN 12697-25, Bituminous mixtures - Test methods, Part 25: Cyclic compression 624 test, British Standard and European Committee, London, United Kingdom, 2016. 
[32] BS EN 12697-44, Bituminous mixtures - Test methods for hot mix asphalt, Part 44:

626 Crack propagation by semi-circular bending test, British Standard London, United

627 Kingdom, 2010.

628 [33] M. van de Ven, A.d.F. Smit, R.L. Krans, Possibilities of a semi-circular bending test, 629 Eighth International Conference on Asphalt PavementsFederal Highway Administration, 6301997.

631 [34] H. Chen, Q. Xu, S. Chen, Z. Zhang, Evaluation and design of fiber-reinforced asphalt mixtures, Materials \& Design 30(7) (2009) 2595-2603.

[35] M. Mohammed, T. Parry, N. Thom, J. Grenfell, Investigation into the bond strength of bitumen-fibre mastic, Construction and Building Materials 190 (2018) 382-391.

635

[36] K.E. Kaloush, K.P. Biligiri, W.A. Zeiada, M.C. Rodezno, J.X. Reed, Evaluation of fiberreinforced asphalt mixtures using advanced material characterization tests, Journal of Testing and Evaluation 38(4) (2010) 400-411.

[37] T. Lopez-Montero, R. Miro, Differences in cracking resistance of asphalt mixtures due to ageing and moisture damage, Construction and Building Materials 112 (2016) 299-306.

640 [38] F. Xiao, S. Amirkhanian, C.H. Juang, Rutting resistance of rubberized asphalt concrete

641

642 pavements containing reclaimed asphalt pavement mixtures, Journal of Materials in Civil Engineering 19(6) (2007) 475-483.

643 [39] Q. Lu, J.T. Harvey, Evaluation of moisture sensitivity of hot mix asphalt by flexural 644 beam fatigue test, Asphalt Concrete: Simulation, Modeling, and Experimental 645 Characterization2006, pp. 124-133.

646 [40] R. McDaniel, H. Soleymani, A. Shah, Use of reclaimed asphalt pavement (RAP) under 647 Superpave specifications: A regional pooled fund project, (2002).

648 [41] A. Apeagyei, W. Buttlar, B. Dempsey, Moisture damage evaluation of asphalt mixtures 649 using AASHTO T283 and DC (T) fracture test, Urbana 51 (2006) 61801.

[42] Z. Wu, L.N. Mohammad, L. Wang, M.A. Mull, Fracture resistance characterization of superpave mixtures using the semi-circular bending test, Journal of ASTM International 2(3) (2005) 1-15.

[43] X.-J. Li, M. Marasteanu, Using semi circular bending test to evaluate low temperature 654 fracture resistance for asphalt concrete, Experimental mechanics 50(7) (2010) 867-876.

[44] E. Zegeye, J.-L. Le, M. Turos, M. Marasteanu, Investigation of size effect in asphalt 657 mixture fracture testing at low temperature, Road Materials and Pavement Design 13(sup1) (2012) 88-101.

[45] A. Razmi, M. Mirsayar, On the mixed mode I/II fracture properties of jute fiber659 reinforced concrete, Construction and Building Materials 148 (2017) 512-520.

660 [46] Q. Xu, H. Chen, J.A. Prozzi, Performance of fiber reinforced asphalt concrete under 661 environmental temperature and water effects, Construction and Building materials 24(10) 662 (2010) 2003-2010.

663 [47] K.P. Biligiri, S. Said, H. Hakim, Asphalt Mixtures, International Journal of Pavement 664 Research and Technology 5(4) (2012) 209-217. 